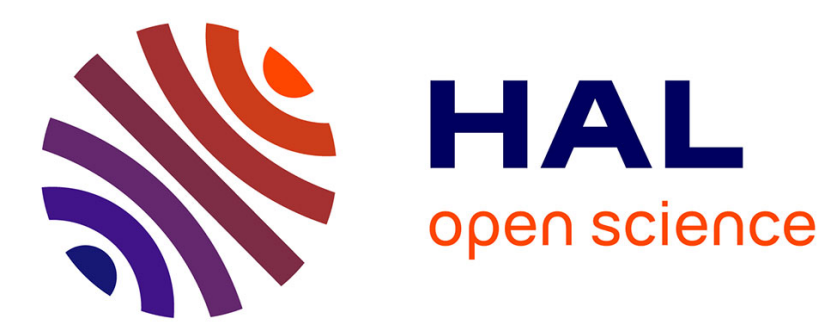

\title{
Roman wall-painting in southern Gaul (Gallia Narbonensis and Gallia Aquitania)
}

Alexandra Dardenay

\section{To cite this version:}

Alexandra Dardenay. Roman wall-painting in southern Gaul (Gallia Narbonensis and Gallia Aquitania). Journal of Roman Archaeology (JRA), 2018, 31, pp.53 - 89. 10.1017/S1047759418001241. hal-01912180

\section{HAL Id: hal-01912180 \\ https://hal.science/hal-01912180}

Submitted on 20 Jun 2021

HAL is a multi-disciplinary open access archive for the deposit and dissemination of scientific research documents, whether they are published or not. The documents may come from teaching and research institutions in France or abroad, or from public or private research centers.
L'archive ouverte pluridisciplinaire HAL, est destinée au dépôt et à la diffusion de documents scientifiques de niveau recherche, publiés ou non, émanant des établissements d'enseignement et de recherche français ou étrangers, des laboratoires publics ou privés. 


\section{Roman wall-painting in southern Gaul (Gallia Narbonensis and Gallia Aquitania) \\ Alexandra Dardenay}

In the Greek world, the practice of decorating walls with painted stucco emerged in the 5 th or 4 th c. B.C. and was at first limited to public and religious monuments and the palaces of rulers, later spreading to the houses of the aristocracy. In the homes of the nobility, painted decoration enhanced the ornamentation of rooms used for receiving visitors, such as the dining room (andron), in which the floors were sometimes decorated with mosaics, most often with geometric motifs. In the wealthiest abodes, as seen at Pella in the 4th c. B.C., Alexandria, or on Delos in the 2nd c. B.C., a mosaic picture called an emblema sometimes lay at the centre of the mosaic. In the realm of domestic art, in the Hellenistic age images were restricted to the mosaic floors. The walls were ornamented with architectural elements that imitated, in stucco relief, the fashions that could be seen in the masonry and marble veneers of temples and palaces. This type of décor, established in the homes of Greek nobility throughout the Hellenistic era, is traditionally known as the masonry style or incrustation style. ${ }^{1}$

Over the course of the 2nd c. B.C., with the Roman conquest of Hellenistic kingdoms, Roman aristocrats discovered not only the marvels of Greek art but also the comfort of Greek homes. The example of Pompeii allows us to document the gradual transformation of the traditional Italic domus into a Greek-style residence, more oriented toward pleasure and leisure (otium). The richest citizens of Pompeii added to the atria of their houses a peristyle onto which several dining rooms (triclinia) opened. To complete the transformation, they commissioned mosaics for the floors and painted-stucco décor for the walls. One of the most grandiose examples of these early Greek-style houses in Italy is the Casa del Fauno at Pompeii, which, at 3,000 $\mathrm{m}^{2}$, was the largest at the time of the eruption in A.D. 79. ${ }^{2}$ Under the influence of the Greek models, and doubtless also because the first artisans and workshops to decorate Roman houses came from Greece, the same type of décor seen throughout the Hellenistic world was reproduced in the Roman world. ${ }^{3}$ The masonry style, with its architectural elements such as orthostats sitting atop a socle, developed further in Italy, where it is known as the First Pompeian Style ${ }^{4}$ (fig. 1). It was in the 19th c. that A. Mau established this four-style classification, based on wall-paintings in the region of Vesuvius. ${ }^{5}$ Because most of his examples came from Pompeii, the classification became known as the "Pompeian Styles". For the most part, his system of classification is followed to this day, although subsequent work has refined the chronology of the phases and the transitions between them. Even so, as is the case with all normative tools, it must be applied

1 On the Greek antecedents, see R. Ling, Roman painting (Cambridge 1991) 12-14; F. Alabe, "Vocabulaire et syntaxe de décors pariétaux hellénistiques," Pitture ellenistica in Italia e in Sicilia. Linguaggi e tradizioni (Rome 2011) 39-48.

2 See A. Hoffmann and A. Faber, Die Casa del Fauno in Pompeji (VI 12). Bd. 1 (Wiesbaden 2009); S. De Caro, I mosaici: la Casa del Fauno (Naples 2001); F. Pesando, "Autocelebrazione aristocratica e propaganda politica in ambiente privato: la Casa del Fauno a Pompei," CahGlotz 7 (1996) 189228; G. Sauron, L'art romain des conquêtes aux guerres civiles (Paris 2013) 22-38. 


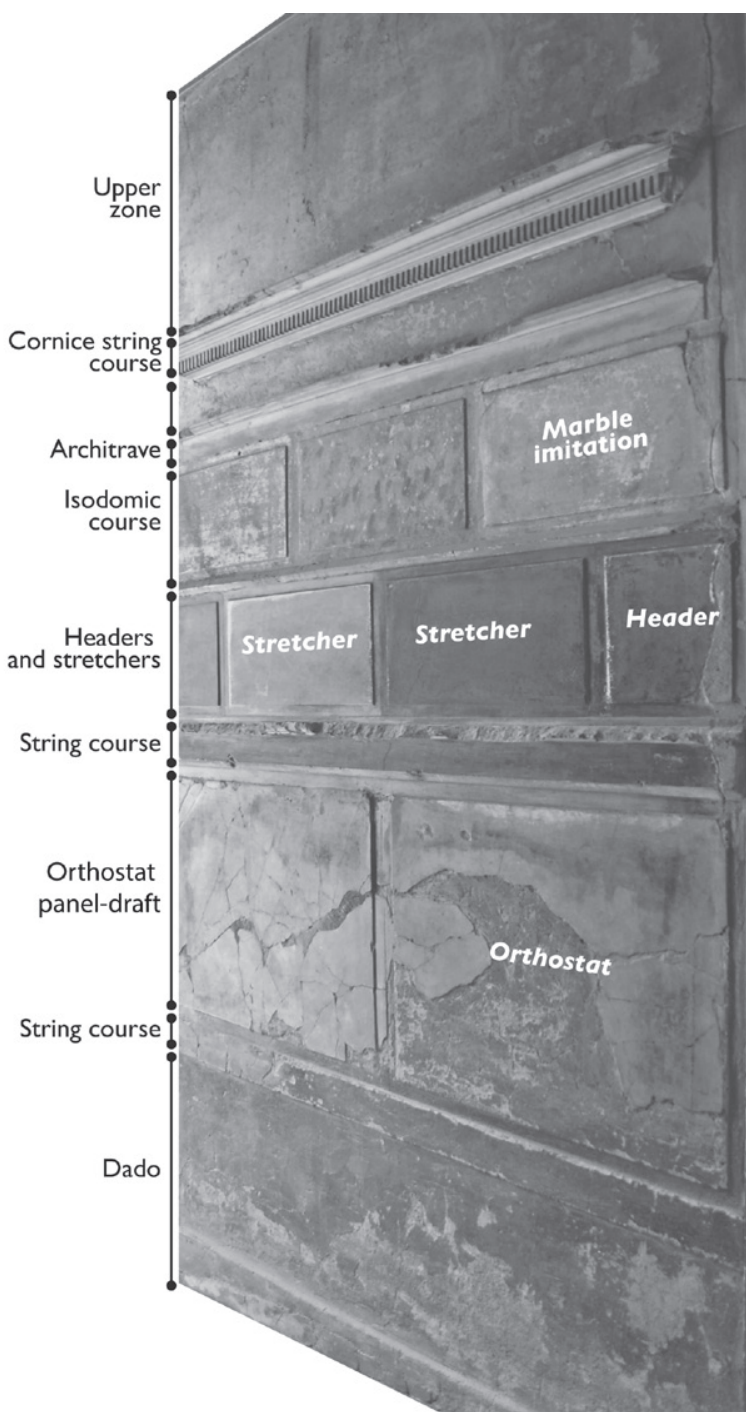

Fig. 1. Key to First-Style decoration. Herculaneum, Samnite House, fauces (DAO: A. Dardenay and M.-L.Maraval).

centuries that followed remained highly dynamic and subject to constant innovation and renewal. The foundations of this conclusion lie in the study of provincial painting, since Italian examples for the period (with the exception of Ostia) are few.

\section{The introduction of mural painting in Gaul}

The First Style is not well represented in Gaul. This is unsurprising, as in most homes that were occupied continuously older styles usually gave way to styles more in fashion as tastes changed. Let us not forget that the inhabitants of these homes would not hesitate, when they had the means, to replace murals considered to be dated or out of style.

Another aspect of the diffusion and preservation of the First Style in Gaul is related to the historical and social context of the introduction of wall-painting to the province. Southeast Gaul (Narbonensis) had a long history of contact with Greco-Roman culture. As early as the 6th c. B.C., the Greeks established trading posts beyond the Alps along the 


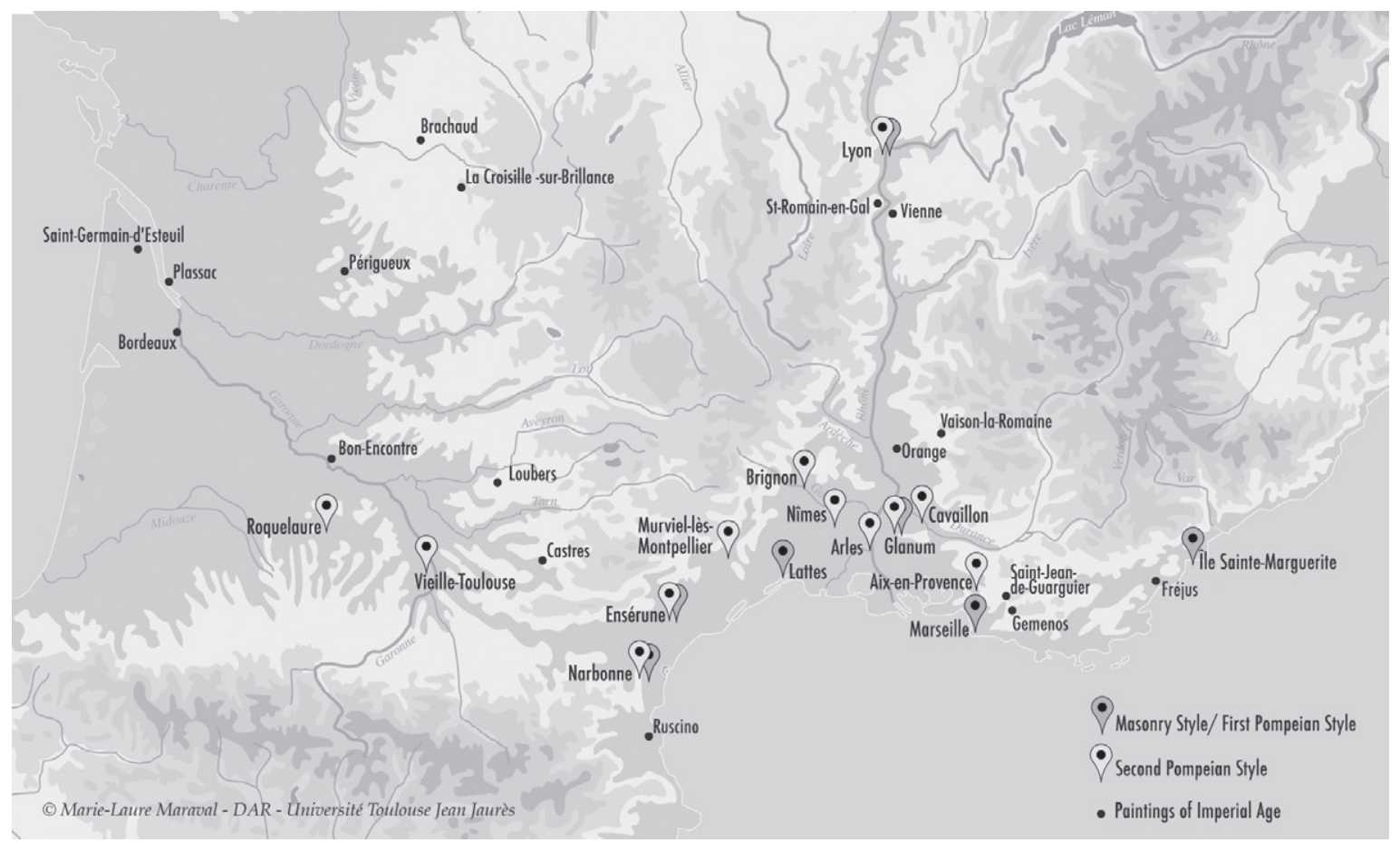

Fig. 2 . Map showing introduction of the masonry style (First Style) in Gaul (DAO: M-L. Maraval).

Mediterranean coast, founding such cities as Marseilles, Nice, Antibes and Agde. Early Greek settlement explains the more extensive acculturation reflected among the populations in the Hellenistic decorative arts. It is for this reason that the masonry style or incrustation style (fig. 2) is widely attested in Narbonensis but absent in other regions of Roman Gaul. ${ }^{6}$ Further, in contrast to the decorative traditions of other provinces, those of Narbonensis adhered more closely to Italian models. This can be explained in part by the geographic proximity, which facilitated the establishment of workshops and the coming and going of urban élites - always the arbiters of taste - along with the pictorial conventions that emerged in Rome. The antiquity of the Greek, then the Roman settlements in the area also made the populations more receptive to Greco-Roman influences. P. Gros has evoked the "phenomena of development by which these peoples benefittd from contact with the Greeks and which contributed greatly to the ease of their political and cultural integration in the Roman world". Italian influence expanded in the transalpine region with, from the 3rd c. B.C., the import of goods from Campania, then from Latium and Etruria, along commercial channels that developed around Marseilles. ${ }^{8}$ Later, the presence of Italian merchants grew greater still after Marseilles appealed to Rome for aid in its struggles against Ligurian pirates. Roman influence culminated after the foundation of the first Roman cities (starting with Colonia Narbo Martius in 118 B.C.), the total conquest of the transalpine region, and then the definitive administrative organisation of the region under Augustus. We refer here to the province of Narbonensis, whose capital was Narbonne.

6 With notable exceptions, such as décors from Lyon or Titelberg: A. Barbet, La peinture murale en Gaule romaine (Paris 2008) 39.

$7 \quad$ P. Gros, La Gaule narbonnaise: de la conquête romaine au IIIe siècle apr. J.-C. (Paris 2008) 13.

$8 \quad$ Ibid. 15-18, on the intervention of Rome and the conquest of the Transalpine region. 
Such trading posts should offer examples of the common types of décor in the Hellenistic masonry style, but there are few examples remaining.9. This scarcity is not due entirely, however, to bad luck; in the 3rd-1st c. B.C. and up to the dawn of the empire, only the wealthiest few had the means to decorate their dwellings in the Greek style, with mosaics and painted murals. Pompeii provides evidence for the claim that it was not until the middle of the 1st c. A.D. that a certain "democratization" of domestic décor occurred, for it is only after the A.D. 40s or 50s, in the reign of Nero, that one finds décor of the Fourth Style in middle-class homes and not exclusively among the wealthy nobles. ${ }^{10}$ Thus, in the context of a Greek colony like Marseilles or Glanum, and even that of the first Roman colonies like Narbonne, we should expect very few examples of homes decorated with mural paintings. This type of décor was also not systematically applied in public monuments and religious sanctuaries, where there was a preference, when the means of the patron allowed, for marble or stone veneers on the walls. Still, S Gaul is not completely devoid of examples in the First Pompeian Style, the Roman variation of the Greek masonry style. ${ }^{11}$ A beautiful, though fragmentary, example was recovered at Isle Sainte Marguerite, very close to the natural boundary of the Alps. ${ }^{12}$ The preserved fragments show a sequence characteristic of imitation stone and marble, including bossed masonry and ornaments in relief stucco. The patchy, multi-coloured effect was not necessarily intended to imitate a particular marble but simply to suggest a more expensive material such as those present in the palaces of Hellenistic rulers, for example. Thus far, there are no examples of this type of decoration in Gaul outside Narbonensis and the Rhône valley in the area south of Lyon, so that the distribution of wall-paintings is a fairly accurate reflection of the penetration of Greco-Roman culture into Gaul before the conquest (fig. 2).

\section{The Second Style in Italy}

In Italy, it was in the Late Republic (80-30 B.C.) that the Second Pompeian Style emerged, in which a trompe-l'oeil effect replaced relief stucco. It was subject to several successive phases ${ }^{13}$ but also several 'versions', ranging from the modest (the "schematic") to the sophisticated (the "scenographic"), which depend on the elaborateness of the architecture being depicted. The earliest examples, such as the House of the Griffins on the Palatine, dated to c.80 B.C., are clearly pictorial adaptations in trompe-l'oeil of the relief stucco elements of the First Style. ${ }^{14}$ One can see this in the arrangement of orthostats in the middle zone, which rest on a socle in imitation of a podium and are topped by courses of isodomic stretchers. The novelty lies in the colonnade running from the foreground seemingly into the distance, which is systematically present in nearly all examples of the Second

Barbet (supra n.6) 37-39 mentions some sporadic discoveries at Glanum, Narbonne and Marseille. As shown by J.-M. Croisille and Y. Perrin. See Croisille, Poésie et art figuré de Néron aux Flaviens (Thèse, Université de Paris IV, 1976; Université de Lille III, 1978); Perrin, "La peinture pariétale italienne de Claude à Titus: le temps des notables," in L'autocélébration des notables dans le monde romain: contextes, images, textes, IIe s. av. J.-C. - IIIe s. après J.-C. (Clermont-Ferrand 2004) $365 \mathrm{ff.}$

Unlike the other provinces of Gaul or even of Germany, where these discoveries are absent. On the other hand, there are some in Spain: cf. C. Guiral Pelegrin and A. Mostalac Carillo, "Avance sobre la difusión de los cuatros estilos pompeyanos en Aragón," Pictores per provincias (Avenches 1987) 233-41.

This is the only one well-documented by archaeology: Barbet (supra n.6) 37-39.

H. G. Beyen, Über Stilleben aus Pompeji und Herculaneum (Copenhagen 1928); Ling (supra n.1) 23-31 (first phase), 31-42 (second phase).

Ling ibid. 23-25 with figs. 20-21. 
Style except those of the "schematic" version. In the latter, the (understated) composition is represented on a single plane. Over the half-century during which Second Style was in fashion, the trend was toward increasingly pronounced 'vistas', painted to create the illusion of a window opening onto an exterior scene, that afforded a view of architectural features rendered in perspective. At first, these openings were small and set in the upper zone of the wall; later they were enlarged and moved to the middle zone. The richest and most spectacular examples of this style are termed "scenographic" because they evoke painted theatrical backdrops, like the façades of Hellenistic palaces. The villa of P. Fannius Synistor at Boscoreale provides a sampling of these decorative elements, ranging from the fairly simple to the highly complex and sophisticated. Among the more restrained examples, we can point to one in the Louvre ${ }^{15}$ which is depicted on two planes. By contrast, an example in the Musée d'Amiens displays a richer repertoire, with a heavy, draped garland characteristic of the period (later on, garlands became finer) in its middle zone and a cornice of metallic panels painted in trompe-l'oeil in the upper zone. ${ }^{16}$ The sophistication of these decorative elements depends largely on their architectural context, ${ }^{17}$ the walls decorated with garlands normally (but not exclusively) appearing in triclinia, but surprisingly scenographic paintings appear frequently not in the areas of public reception, but in small bedrooms (e.g., cubiculum M in the villa of P. Fannius Synistor, restored in New York's Metropolitan Museum of Art). ${ }^{18}$ The Second Style is also marked by another novelty: lifesize figures in domestic wall-paintings. ${ }^{19}$ Though they sometimes appeared in Hellenistic and Etruscan tomb paintings, we know of no examples of large-scale figures in the murals of private homes or even public monuments before the middle of the 1st c. B.C. A magnificent example dating to 50-25 B.C. is the "Winged Genius" of Boscoreale who greets the visitor on either side of a door opening from a peristyle to an oecus. ${ }^{20}$

The spread of the Second Style in Gaul

Again, Late Republican domestic wall-paintings of the Second Style were introduced to Gaul only in the homes of the nobility, those of Romans settled in Gaul on temporary or long-term appointments, and of local élites who sought to imitate the lifestyles and

15 É. Dubois-Pélerin, A. Barbet and A. Verbanck-Piérard, La villa romaine de Boscoreale et ses fresques, vol. I. Description des panneaux et restitution du décor (Paris 2013) 22-24; V. Tran Tam Tinh, Catalogue des peintures romaines, Latium et Campanie, du Musée du Louvre (Paris 1974) 49, fig. 29. Panel P.102 (MND 616). B. Bergmann, Roman frescoes from Boscoreale: the Villa of Publius Fannius Synistor in reality and virtual reality (New Haven, CT 2010) figs. 17-18.

16 Dubois-Pélerin et al. ibid. 71-72. Bergmann, ibid. figs. 30 and 32. F. Barnabei, La villa pompeiana di P. Fannio Sinistore scoperta presso Boscoreale (Rome 1901) 42-43.

17 At all times one notices the presence of much simpler ornamental systems, not only in less affluent homes but also in the side rooms of élite houses. It is what V. M. Strocka (Neue Forschungen in Pompeji und den anderen vom Vesuvausbruch 79 n.Chr. verschütteten Städten [Berlin 1975] 101-16) called "Nebenzimmer". See also C. Liedtke, Nebenraumdekorationen des 2. und 3. Jahrhunderts in Italien (Berlin 2003) and W. Ehrhardt, Dekorations- und Wohnkontext: Beseitigung, Restaurierung, Verschmelzung und Konservierung von Wandbemalungen in den kampanischen Antikenstätten (Wiesbaden 2012).

18 Ling (supra n.1) fig. 28, pp. 29-33.

19 On Second-Style paintings from the élite houses, see G. Sauron, La peinture allégorique à Pompéi: le regard de Cicéron (Paris 2007).

20 On this décor, ibid. 68-73. The décors from Boscoreale were drawn in a virtual model @ KVL, King's College London. See Bergmann (supra n.15) figs. 28, 34 and 35 for the winged guardian figures. 
fashions of the former. Among the earliest examples of the adaptation of the Second Style in Gaul, the most complete are at Glanum, in particular those from the "Maison aux deux Alcôves" in which the wall-paintings (figs. 3a-b in colour) were completed between 50 and 30 B.C. ${ }^{21}$ The house shows the luxury of a noble household in Narbonensis at the end of the 1st c. B.C. One room is decorated in the relatively restrained "schematic" Second Style: on a white background, above a lower zone decorated with scrollwork sticks, there is a row of bossed orthostats in rather simple black or white outline. This room opens onto a small cubiculum decorated in a more sophisticated version of the Second Style, with trompe-l'oeil imitations of polychrome marble blocks forming both the orthostats and the rows of headers and stretchers above them. Thus at Glanum, as in Italy, the hierarchy of wall-paintings reflects a hierarchy of domestic spaces based on both the function of the rooms and the status of the occupants. In general, in residences of the 1st c. A.D. the finest wall-paintings were reserved for the reception areas and bedchambers.

The recent discovery of a Late Republican ensemble at Arles, at the site of La Verrerie, provides the first example in Narbonensis of a megalographic wall-painting in the Second Style, in which one or several isolated figures are set against a red background in the medial zone. Dating to the middle of the 1st c. A.D., this rich and rare painting is contemporary with the examples from the Villa of the Mysteries or Villa of P. Fannius Synistor. ${ }^{22}$ At Arles, several fragments of figures suggest a Dionysiac atmosphere; the best-preserved figure is a young woman who is clearly playing a musical instrument, perhaps a harp.

The effect of the paintings (figs. 4a-b in colour) discovered at Roquelaure (Aquitaine) must have been even more spectacular. They are among the oldest paintings of comparable quality in Gaul outside Narbonensis but their interpretation and dating has been complicated by the restoration work done in the 1960s. ${ }^{23}$ The fragments recovered during the excavations were re-assembled in several panels reconstructing two main décors, but those panels are museological re-imaginings intended to render the images more legible to the public rather than strict archaeological reconstructions of the works as they would have looked. In other words, closer attention was paid to the chromatic palette and general harmony than to considerations of stylistic and chronological coherence. We find fragments that are distinctively Third Style in their decoration associated with architectural elements of the Second Style. Yet, in spite of these errors, it is possible to grasp the general framework of an impressive architectural composition of the late Second Style. ${ }^{24}$ The best

21 A. Barbet, “Les peintures de Glanum: une relecture," Gallia 47 (1990) 103-34.

22 J. Boislève, M.-P. Rothé and A. Genot, "Le site de la Verrerie à Arles et ses exceptionnels décors de IIe style pompéien," in J. Boislève, A. Dardenay and F. Monier (edd.), Pictor 5. Peintures et stucs d'époque romaine. Une archéologie du décor (Bordeaux 2016) 75-94. J. Boislève, M.-P. Rothé and A. Genot, "Un nouveau décor de deuxième style sur le site de la Verrerie à Arles," in J. Boislève, A. Dardenay and F. Monier (edd.), Pictor 6. Etudes toichographologiques (Bordeaux 2017) $\underline{000-00 .}$

23 A. Barbet, "La diffusion du IIIe style pompéien en Gaule (deuxième partie)," Gallia 41 (1983) 111-65.

24 Barbet proposes a reconstruction of this décor in Gallia 41 (ibid.). See also A. Dardenay and P. Gardes, "Les peintures murales de Roquelaure. Reprise des fouilles, nouvelles découvertes et perspectives futures," Pictor 5 (supra n.22) 11-26; P. Gardes et al., "Les maisons romaines précoces de l'oppidum de la Sioutat à Roquelaure (Gers)," Gallia 70 (2013) 25-57; I. Baldassarre, A. Pontrandolfo Greco and A. Rouveret (edd.), La peinture romaine: de l'époque hellénistique à l'Antiquité tardive (Arles 2006) 117-18 (with the same dating for this décor). 


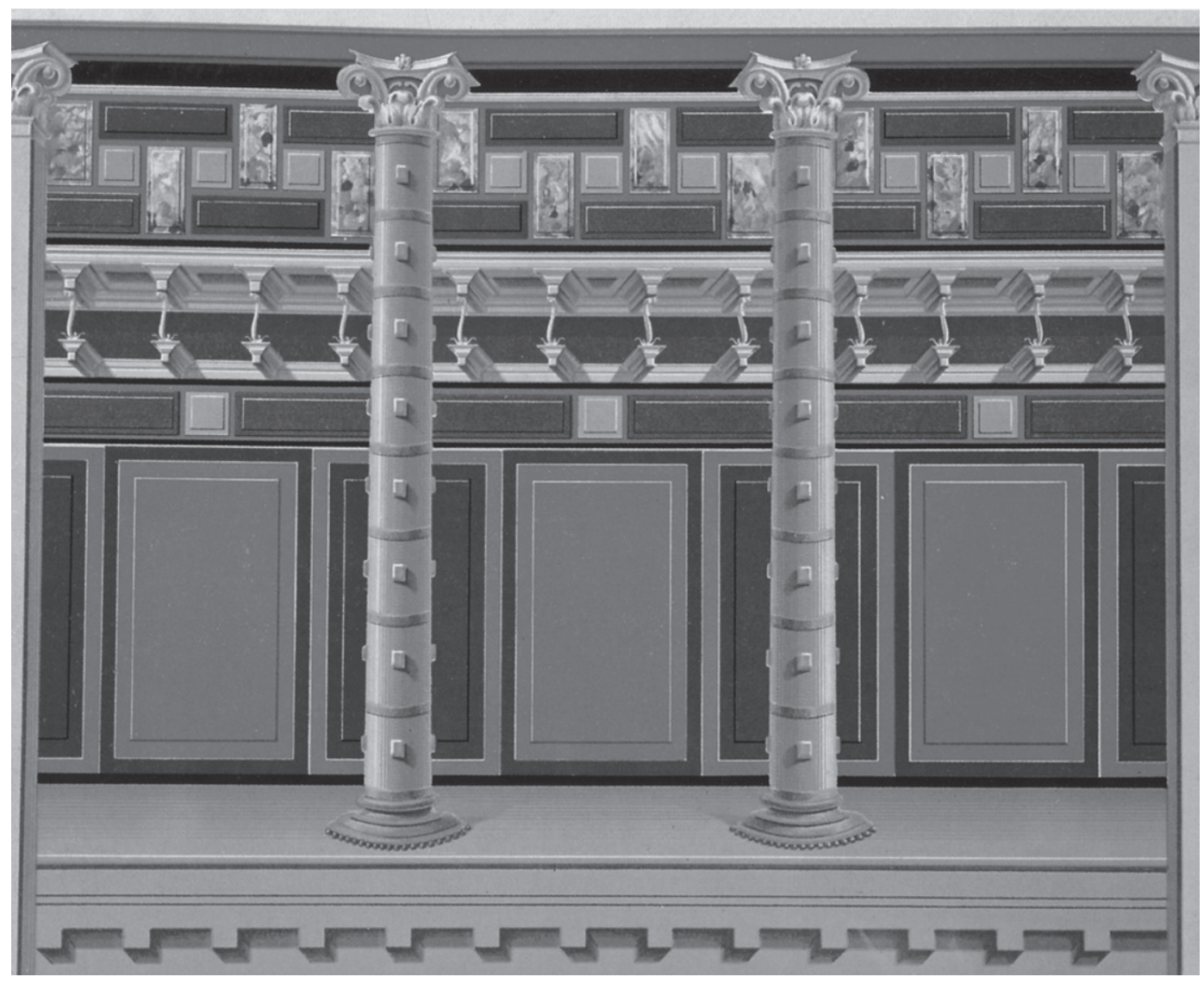

Fig. 5. Pompeii, Casa delle Nozze d'Argento. First phase of the Second Style (reconstructed according to Maisons et monuments de Pompéi dans l'ouvrage de Fausto et Felice Niccolini [préf. S. de Caro; Paris 1997])

Italian examples of architectural designs of such quality in trompe-l'oeil are to be found in the grand aristocratic dwellings of the early Augustan age, such as the so-called houses of Augustus (room of the Masks) and of Livia on the Palatine, or the villa at Oplontis. ${ }^{25}$

In a row of columns in a wall-painting in Pompeii's Casa delle Nozze d'Argento (fig. 5) one can perceive both the junctions between the column drums and the tenons used to lift them into place. This corresponds to a trend towards highly detailed representations that spans the Second Style and crosses into Gaul, as seen in a fine example at Roquelaure. The same composition as in the Pompeian house can also be found at Glanum, in the House of Sylla (XII, Room D). The upper zone is organized identically with a triple row of headers, in which the blocks are positioned sometimes horizontally, sometimes vertically. There is also a similar approach with regard to the imitation of specific materials, in particular polychrome marbles.

The reign of Augustus and the "aesthetic revolution" in Gaul

With the reign of Augustus, a new aesthetic triumphed. The massive architectural features of the Second Style gave way to one-dimensional compositions, without perspective or effects of depth. The wall-paintings are spare and subdued, often monochromatic but with a definite preference for chiselled motifs, inspired by goldsmithing, jewelry and the 
decorative arts, and using muted tones such as mauve and light green. This type of mural, in which slender colonnettes or candelabra replaced robust columns, appeared in the circle of Augustus by the 20s B.C. and spread in the following years. The monochromatic red wall-paintings of the Villa of Agrippa Postumus at Boscotrecase, in which the restraint and the love of empty space are equalled only by the refinement of the rare embellishments that break the monotony, is a perfect example of the decline of architectural themes that accompanied the dawn of the Third Style. ${ }^{26}$

The Third Style arrived early in Gaul, doubtless with the installation of Augustus at Lyon from 16 to 13 B.C., ${ }^{27}$ and was most notably characterized by candelabra panels (décors à candélabres). Much prized by the élites of Roman Gaul, this motif spread widely and passed through several variations. The murals at Aix-en-Provence's Aire du Chapitre, ${ }^{28}$ in several characteristics recall the "Black Room" in the Villa of Agrippa Postumus: in both cases we find the areas between the panels divided transversely by very fine rods in imitation of metalwork. An early example of the candelabrum motif (fig. 6 in colour) was found at Périgueux in the domus of Vesunna. ${ }^{29}$ Here, in the central zone, red panels adorned with fine garlands in a faux beadwork style hang beneath miniature pictures with white backgrounds. The scansion between the panels is marked by fine candelabra "à roulettes". The metallic aspect of these candelabra is taken from the furniture on which they are modelled, typical of Roman décor of the early Third Style.

Over the course of the Third Style, a taste developed for painted and miniature pictures at the centre of the panels of the middle zone. At first they occupied only the central panel, but later they multiplied, spreading to the lateral panels and going so far as to form true picture galleries, a trend that would reach its culmination in the Fourth Style. In these pictures and miniatures, scenes borrowed from mythology stand beside landscapes and still-lifes, the genres sometimes blending to form the sacro-idyllic landscapes in which Roman painters excelled. ${ }^{30}$

The wall-painting in the Villa Roma at Nîmes (fig. 7 in colour) is a classic example of the canons of the Third Style. ${ }^{31}$ In the middle zone of the central panel, against a maroon background, is a picture of a young hero in a composition similar to that of mythological pictures known from Pompeii. Several comparisons are possible with scenes of Meleager and Atlanta or Endymion and Selene on the Italian sites. The panels of the middle zone rest on a predella with a black background, as in the examples at Aix's Aire du Chapitre. The theme depicted, in which dwarfs parody well-known scenes of Greco-Roman mythology, is rare in Gaul despite being popular in Italy. At Nîmes, the scene parodied is a famous one from the Iliad: Ajax abducting Cassandra from the shrine of Athena. The frieze of dwarfs at the Casa del Medico in Pompeii that parodies the Judgment of Solomon ${ }^{32}$ confirms the Roman taste for irreverent satire of great literary works.

$26 \quad$ Ibid. 55, fig. 55.

27 Barbet (supra n.6) 102-3.

28 Ibid. 105-6.

29 A. Barbet et al., "Peintures de Périgueux. Édifice de la rue des Bouquets ou la Domus de Vésone," Aquitania 24 (2008) 42-76.

30 J.-M. Croisille, Paysages dans la peinture romaine: aux origines d'un genre pictural (Paris 2010).

31 M. Sabrié, R. Sabrié and M. Piskorz, "Les peintures murales de "Villa Roma” à Nîmes (Gard) Persée," RANarb 31 (1998) 13-71.

32 MANN inv.113197; I. Bragantini and V. Sampaolo, La pittura pompeiana (Milan 2013) 417, no. 215. 
Flying figures are favoured in the Third Style, and became a common motif in the central panels of the Fourth. In the décor from Vaison-la-Romaine, north of the Cathedral, ${ }^{33}$ there were once, above a socle, two red ocre panels decorated, respectively, with a cupid armed with a bow and arrows and a winged genius holding a vase and palm frond (fig. 8 in colour). These two figures undoubtedly graced the lateral panels, bordering a large, central aedicula whose decoration is now lost. These winged figures belong to the Italian repertoire, exemplified at Pompeii in the triclinium of the Casa di Orfeo (VI.14.20), ${ }^{34}$ where we find a hortus conclusus motif in the predella beneath the central picture.

In Italy, the final phase of the Third Style (A.D. 20-30) is characterized by the gradual re-introduction of the architectural themes and visual illusions of the Second Style. Such come-and-go trends in the popularity of certain themes are not unknown in art history. Similarly, it can be noted that in Italy the revival of robust architectural features and of scenographic views that culminate during the Fourth Style receded under Trajan and Hadrian, ${ }^{35}$ giving way once more to flat and linear compositions, like those at Ostia. ${ }^{36}$ But north of the Alps the new illusionistic revolution, the return to architectural trompe-l'oeil in painting that characterizes the end of the Third Style and start of the Fourth, for the most part and with rare exceptions, was not followed. The phase of exact reproduction of Third-Style paintings was rather brief, practiced by the first generations of painters and ateliers in Gaul who came directly from Italy. It is likely that by the start of the 1st c. A.D. - a period of growing demand for Roman-style wall-paintings among the Gallic élites ateliers would have become more firmly established in Gaul, apprenticing new painters locally. The movement of artists between ateliers in Italy and Gaul would have diminished greatly or even largely eased. The new generations of painters would have been less strongly influenced by the Italian tradition, been less familiar with metropolitan modes and conventions, and instead developed original themes and compositions. Nonetheless, they continued to be influenced for a considerable time by the wall-painting conventions that were in vogue in the Augustan age at the time of their initial diffusion into Gaul. The strong impression of the "aesthetic revolution" explains not only the permanence of the "candelabrum style", but also its subsequent variations.

The second half of the 1st c. A.D. and the triumph of inter-panel candelabra

The second half of the 1st c. A.D. marks a period of relative autonomy in provincial wallpainting. If we exclude a few examples from Narbonensis, a province that seems to have remained relatively permeable to Italian influence (with good reason, given its proximity to the Alps but also its long-established communities of Italian origin), the Fourth Style, such as we observe it in Italy, does not seem to have been adopted in Gaul. In discussing this phase of painting in the Roman provinces, it is therefore more judicious to set aside the label of "Fourth Style" in favour of the term "Flavian painting", easily remembered if a bit reductive chronologically, or the more precise "painting of the second half of the 1st c.". Studios in Gaul maintained the more economical elements of the illusionist phase of the Pompeian Fourth Style but did not adopt the architecturally-inspired inter-panel

C. Allag, Peintures romaines: Musée de Vaison-la-Romaine (Vaison-la-Romaine 1987) 28-29, fig. 18a; Barbet (supra n.6) 66-67.

34 M. De Vos, L'égittomania in pitture e mosaici romano-campani della prima età imperiale (place 1980) 14, tav. IX.2.

35 Ling (supra n.1) 78-81.

36 S. Falzone (ed.), Scavi di Ostia XIV. Le pitture delle "Insulae", 180-250 circa d.C. (Rome 2004). 
decorative elements so characteristic of that phase. Gallic studios also showed only a mild interest in the large-scale mythological scenes and multiple miniatures that transformed the Vesuvian home into a veritable picture-gallery. One of the fundamental originalities of provincial painting lies in a different approach to the distribution of the figurative and decorative elements. In Gaul, the images and motifs were placed not in the middle zone, but in the lower zone and the inter-panel areas. Furthermore, most often (and with the usual exception of Narbonensis, which clung more closely to Roman tastes) the large upper zone was sacrificed, sometimes being entirely absent. ${ }^{37}$ This explains why direct comparisons between Italian examples of the Fourth Style and contemporary provincial examples are not always successful; in any case, they present less striking parallels than do works of the late Republican era.

Vienne (Saint-Romain-en-Gal), on the banks of the Rhône at the N edge of Narbonensis, provides a fine example of the provincial candelabra style in the so-called "Paroi du globe". ${ }^{38}$ Only the most spectacular elements were recorded in the 19th c., but a more complete reconstruction can be proposed (fig. 9 in colour). ${ }^{39}$ Probably no decorative elements interrupted the monochromatic effect of its rich green panels, rare for Gaul. The mural's iconographic effect lay mainly in the lower panel, decorated with medallions bearing swans or masks and, above all, in the superb inter-panel motifs on a black background that bracketed the green panels of the middle zone. In the eponymous example (though it actually bears an armillary sphere, not a globe) a metallic staff seems to emerge from garlands of vegetation rooted in a cantharus. It forms an imitation of a candelabrum, in which the umbellae (circular plates) are ornamented - with vases, birds, garlands and masks - in a sort of horror vacui. The upper umbella bears an armillary sphere decorated with a winged figure, no doubt a victory. Figures standing at the top of a candelabrum are characteristic of wall-painting in Gaul, whereas in Italy they are generally set on architectural elements such as columns, cornices or entablatures. ${ }^{40}$ They tend to occur either in isolation or as supports of the architectural elements in the upper zone, much like caryatids. A fragment from Herculaneum now in the Naples museum (MANN, inv. 8904) is a fine example of figures that are at once mythological and functional (porters, servants) and came to people the architectural elements in paintings. ${ }^{41}$ The swan motif on the "Paroi du globe" recurs on a candelabrum in an ensemble discovered at Saint Florent in Orange and datable to the Flavian era. ${ }^{42}$ On a black socle decorated with tufts of greenery - a direct

R. Sabrié and M. Sabrié, "Style et datation des peintures de la maison à Portiques à Narbonne," Pictores per provincias (supra n.11) 164; H. Eristov, "Les peintures murales provinciales d'époque flavienne," ibid. 48.

O. Leblanc, "La Maison aux Peintures, Saint-Romain-en-Gal (Rhône)," in J. Boislève, A. Dardenay and F. Monier (dir.), Pictor 1. Peintures murales et stucs d'époque romaine. De la fouille au musée. Actes du collooque de Narbonne, 2010 et du colloque de Paris, 2011 (Bordeaux 2013) 207-13. Ibid? 388 .

40 S. Groetembril and F. Monier, "Candélabres gallo-romains à figures en couronnement," in D. Scagliarini Corlaita (ed.), I temi figurativi nella pittura parietale antica: IV sec. a.C. - IV sec. d.C. (Bologna 1997) 54. An Italian antecedent, although very different from the point of view of its function on the wall, could be the metallic candelabra painted on a wall of Boscoreale's Villa of Publius Fannius Synistor, where three winged figures stand on top of a candelabrum.

41 From the Casa di Nettuno ed Anfitrite. For a restoration in a virtual 3D model by the ANR VESUVIA Project, see A. Dardenay et al., "Habitat et société à Herculanum," Chronique act. archéologiques, École française de Rome (2015) fig. 8.

42 Barbet (supra n.6) 123-25. R. Sabrié and M. Sabrié, Peintures romaines en Narbonnaise (Cat. d'expo, Paris 1993) 47. 
import from the Fourth Style - rest large monochromatic panels in red-ochre that alternate with black inter-panel sections decorated with metallic-style candelabra. Swans, their wings spread, adorn the umbellae while an oenochoe crowns the ensemble. Ruscino near Perpignan provides another, equally fine, example in which all the luxury of the painting and skill of the painter are invested in the inter-panel candelabra. ${ }^{43}$ Against a black background a candelabrum rises between the two panels. The ornamental motif of alternating hearts and points that divides the two fields, the "embroidery border" borrowed from the Third Style, endures in provincial painting up to the end of the 1st c. A.D. As in the Italian model, a sphinx, frequent in paintings of the Fourth Style, sits at the end of a cornice above the panels.

The murals at 38-42 Boulevard de la République in Aix-en-Provence (fig. 10 in colour), dated to c.A.D. 50, are also typical of the candelabra style. ${ }^{44}$ Sombre red-ochre panels alternate with maroon inter-panel elements against which magnificent golden candelabras with umbellae stand out. The originality of this piece resides in the maroon colour of the inter-panel elements, which usually had black backgrounds. The arrival and persistence of the candelabrum style in the transalpine region throughout the 1st c. A.D. echoes an aesthetic phenomenon that can be observed to varying degrees throughout Roman Gaul and beyond. In Belgica, Germania, and Lugdunensis as well, candelabra multiplied, occupying increasingly large areas of the wall, though almost always restricted to the inter-panel elements of the central zone.

In spite of these departures, however, the rupture with Italian painting was not complete. Although entire compositions were not strictly re-created or adapted, certain motifs in vogue in Italy can be found in provincial paintings, showing that painters returned periodically to the Italian repertoire to select motifs to their taste that would renew their compositions and maintain a Roman flavour or a metropolitan touch. We thus find in provincial paintings the embroidery borders so typical of murals of the Fourth Style. ${ }^{45}$ The taste for these "wallpaper patterns", which developed in the expansion of wall motifs at Nero's palace, continued in Narbonensis well beyond the 1st c. A.D. In Italy too, these motifs spread widely from the time of Nero's reign under the Fourth Style. A beautiful example is preserved in room C of House III at Narbonne ${ }^{46}$ (fig. 11 in colour). Dated by R. and M. Sabrié to the end of the 2nd c., it follows the traditional tripartite organization, with imitation coloured marble in the central and lower zones, and a "wallpaper pattern" against a white background in the upper zone. In the Fourth Style, examples are numerous of these compositions formed by the repetition of a shape or motif, with the elements standing in isolation or connected at a tangent (adjoining diamonds) or secant (e.g., circles). The potentially unlimited repetition of these motifs creates a geometric framework that can be embellished with floral, ornamental or figurative designs, also following a regular pattern of repetition. In the example at Narbonne, green circles connected by orthogonal green or yellow bands frame red or blue flowers. In Italy, such repetitive motifs range from the very

43 Dated c.A.D. 50-100. M. Sabrié and R. Sabrié, "Ruscino (Chateau Roussillon, Pyrénées Orientales)," Peinture murale romaine. Actes du Xe séminaire de l'AFPMA, 1987 (Paris 1989) 27-34, figs. 8-10; M. Demore and M. Sabrié, Peintures romaines à Narbonne: décorations murales de l'antique province de Narbonnaise (Narbonne 1991) 81-82.

44 Barbet (supra n.6) 107-8 with figs. 138-39.

45 On embroidery borders from Narbonne, see Sabrié and Sabrié (supra n.37)

46 On this type of composition in wall-painting, see E. Formoso, "Les décors à réseau. Des peintures murales surprenantes et méconnues," Dossiers de l'Archéologie 318 (2006) 86-89. 
simple to the highly sophisticated, according to the means of the patron, but their use does not vary with the function or importance of the room, as is shown by their prevalence in the Domus Aurea ${ }^{47}$ or their use in Pompeii's refined residences, such as room I of the Casa degli Amorini dorati (VI, 16, 7) ${ }^{48}$ or in the Casa della Caccia Antica (VII, 4, 48). The primary difference between this last example and that at Narbonne, as far as composition is concerned, resides in the ornamentation of the central zone.

In the second half of the 1st c., examples of "wallpaper patterns" in Narbonensis are primarily restricted to ceiling decorations. ${ }^{49}$ It is not until the 2 nd c. that these motifs spread to the upper zones of walls and enjoyed great popularity in the western provinces. This difference in application is not due to a chronological difference between Italy and the provinces, since the designs are so well documented on ceilings, but was perhaps because the inhabitants of Narbonensis were slower to develop a taste for this type of motif on walls. ${ }^{50}$ This taste apparently did not arrive until the middle of the 2 nd c., perhaps in one of the 'retro' waves so common in the history of art. Furthermore, it was at the end of the 2nd c., the probable date of room C in Narbonne's House III, that the trend shifted toward imitation marble in the lower and central zones of the wall, with the "wallpaper pattern" set just above in the upper zone. The association in wall-painting of imitation marble with geometric motifs was not unknown in Italy (it is seen, for example, in room I of the Casa degli Amorini dorati, though with a reversal of the proportions (one-third imitation marble, two-thirds geometric motif).

The persistence of the upper zone in the wall-painting of Narbonensis in the 1st and 2nd c.

Compared to the other provinces of Gaul, what most characterizes the paintings of Narbonensis is the frequent presence of an upper zone, at a considerable height. While Italian wall-paintings consistently make a tripartite vertical subdivision of the wall, Gallo-Roman paintings outside of Narbonne often abandon the upper zone and divide the wall into two sections: the central zone, which can reach impressive proportions, and the lower one, which serves as the plinth. Although it is not systematic, the use of an upper zone (which reduces the dimensions of the central zone) is seen more frequently in Narbonensis than elsewhere in Gaul. The domus at Place Jules-Formigé in Fréjus (fig. 12 in colour) provides especially clear evidence in the Third-Style décor of its atrium. Above the red panels of the central zone, there is a yellow upper zone decorated with quite flat pseudo-aediculae, in line with the candelabra of the central zone. ${ }^{51}$ Later examples dating to the end of the 1 st $\mathrm{c}$. are found at Narbonne's Maison à Portiques, in rooms G and H in particular. ${ }^{52}$ In the 2nd c., Narbonne again provides clear examples of the continued popularity of the upper zone in rooms A, B, and C of House III. ${ }^{53}$ The upper zone of room A, ${ }^{54}$ with a green background, is a spectacular example, with stylized architectural elements arranged on several planes (fig. 13 in colour). At the center, a bright yellow censer is suspended by a chain; on it, a pair

P. G. P. Meyboom and E. M. Moormann, Le decorazioni dipinte e marmoree della Domus Aurea di Nerone a Roma (Leuven 2013).

Formoso (supra n.46) p. 86 with fig. 1.

49 Barbet (supra n.6) 317-26. compared to the surrounding rooms.

Sabrié and Sabrié (supra n.42) no. 69. 
of opposing phoenixes spread their wings. This painting once crowned a central zone with particularly rich iconography: large pictures with human figures (among them a soldier holding a shield) alternate with large vertical bands ornamented with foliage in the fashion of a straight, stylized candelabra. In room C at Narbonne's Clos de la Lombarde, in a painting that also dates to the 2 nd c., human figures are painted in the upper zone against a white background. ${ }^{55}$ Fairly well preserved, a life-sized (or nearly so) female figure stands wearing a long blue tunic while holding a long staff at an angle; on the head of this deity (or allegory) one can discern a translucent veil and a beaded diadem.

\section{The 2 nd century A.D.}

With the end of the 1st c., the chronology of painting becomes less certain as discoveries (in Gaul as well as in Italy) have been sporadic, making it difficult to establish regional syntheses, much less inter-regional comparisons. Further, we no longer have the Vesuvian sites for reference. Ostia remains the primary source for paintings of the 2nd to 4th c., but examples are far less abundant and less well-preserved than the preceding ones of Campania. The growing autonomy of provincial painting vis-à-vis Italian conventions now becomes increasingly marked, complicating attempts at dating through stylistic comparisons. During the first half of the 2nd c., paintings in S Gaul show no rupture with the preceding decorative conventions, insofar as the candelabrum very often remains a central element of the composition. One of the richest and most complete examples is the "Maison aux Portiques" at Clos de la Lombarde, where the majority of the paintings date to the 2nd c. ${ }^{56}$ Even if provincial painting possesses its own syntax, the vocabulary, as in preceding periods, is still largely borrowed from the Italian tradition. Such is the case at Nîmes, where a panther stands as an acroterion on a cornice, the end of its tail forming a spiral. ${ }^{57}$ A parallel to this motif can be found in a wall-painting at Ostia's Casa delle Muse, dated to the 140 s. $^{58}$

In the second half of the 2nd c., the candelabrum that had served as the principal structural element and the primary iconographic support in wall-paintings little by little fell out of favour. Before disappearing completely, the metallic-inspired version gave way to a floral one that abandoned ornamental umbellae and objects. That is to say, at the centre of the inter-panel elements stalks of plants rose in the place of a candelabrum. This trend toward floral elements is exemplified on a wall (fig. 14) at Bon Encontre's villa de Sainte Radegonde (Lot et Garonne). ${ }^{59}$ Here, against a white background, the panels of the middle zone, which appear to be supported by scrollwork consoles, are decorated with narrative pictures (poorly conserved). Tufts of leaves unfold across the lower zone. Between the two panels stands a stem punctuated with leaves and curling vines that terminate in blue flowers; an interesting detail can be seen in the thin horizontal plates that cross the stalk at regular intervals, substituting for the umbellae. The upper zone is architecturally inspired,

56 M. Sabrié et al., La maison à portiques du Clos de la Lombarde à Narbonne et sa décoration murale: fouilles 1975-1983 (Paris 1987); M. Sabrié, "La Maison à Portiques du Clos de la Lombarde à Narbonne: décoration murale de trois pièces autour de l'atrium," RANarb 22 (1989) 237-86.

59 A. Dardenay, "Circulation des images: place, fonction et interprétation des thèmes iconographiques dans la peinture en Gaule romaine," in F. Monier, C. Balmelle and H. Eristov (edd.), Décor et architecture en Gaule entre l'Antiquité et le Haut Moyen Âge (Aquitania Suppl. 20, 2011) 345-57. 


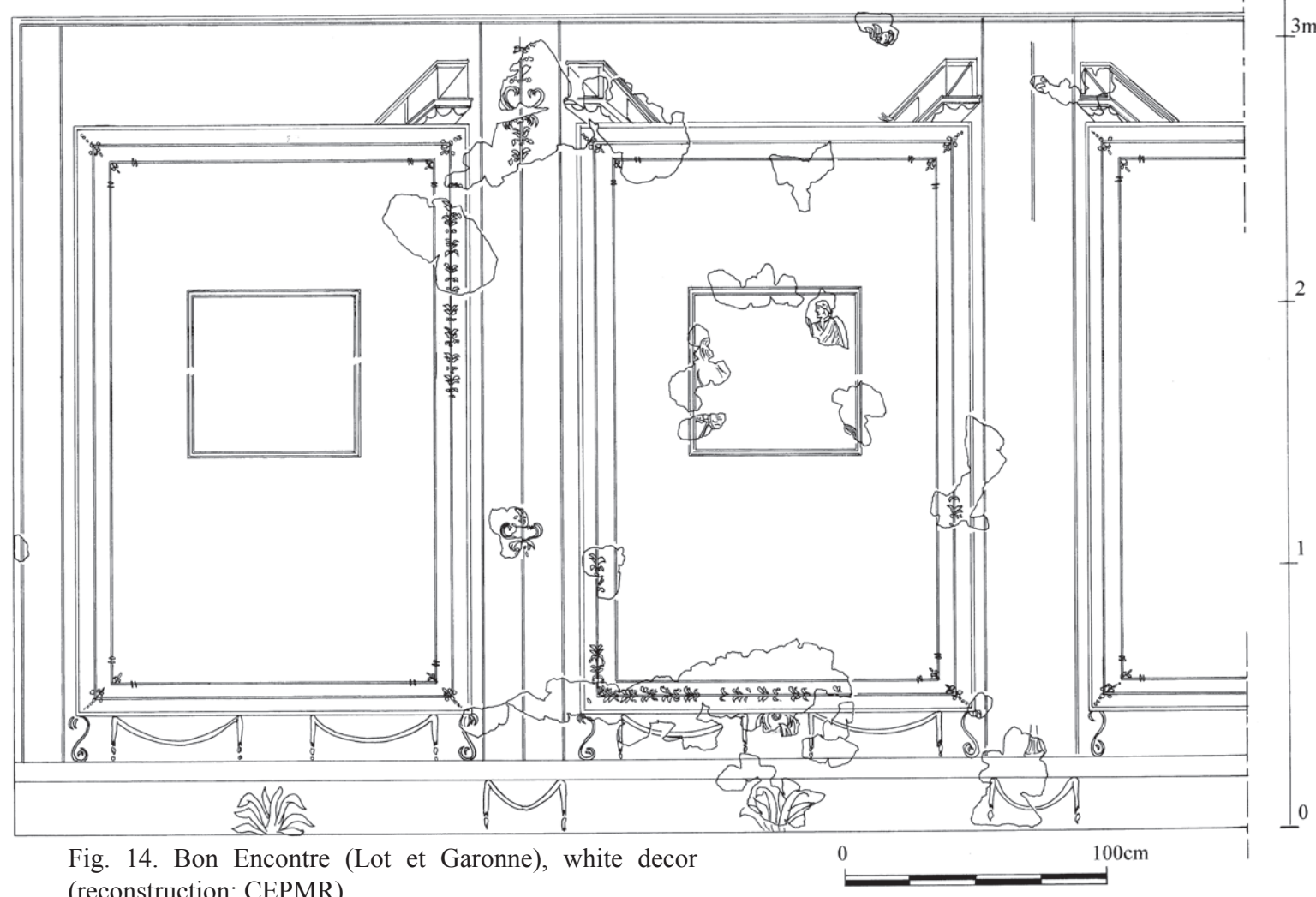

(reconstruction: CEPMR).

with entablatures rendered in perspective. As a whole, this work exemplifies the persistence in provincial painting of the system of panels and pictures inherited from the Third and Fourth Styles.

Similar plant-stems are found in lesser-known paintings in Narbonensis: at Saint-Jean de Garguier (Gémenos) and the Villa Grassi in Aix-en-Provence. ${ }^{60}$. At the former, the stalk seems to spring forth from a glass vial. As at Bon Encontre, the floral motifs are modest, simple touches of green, almost schematized. In the paintings at Gémenos and the Villa Grassi, as in those at Bon Encontre, a preference for white backgrounds is evident in the paintings of the 2nd c.; traces of the architectural style can be detected in the framing of the composition, even in the absence of any overt, realistic representation. The persistence of systems of panels and pictures in 2nd-c. Gaul (at Brachaud, Bon Encontre and Saint-Germain d'Esteuil) is fairly different from what can be observed in Italian paintings of the same era, in which narrative scenes, notably in the form of animated friezes or pictures, are rare. ${ }^{61}$

Old images, new formulae: imitation marble, architectural elements, and large-scale narratives

In the second half of the 2nd c., the abandonment of candelabra (or the stalks of foliage that stood in for them) constitutes a true rupture, paving the way for new compositions. Even so, it was the decorative syntax that changed and not the basic vocabulary, with artists returning to the motifs, architectural forms and material effects exploited from the First through Fourth Styles. Most notably, this period marks the return of imitation marble, so markedly abandoned in provincial painting since the end of the Republican era and the 


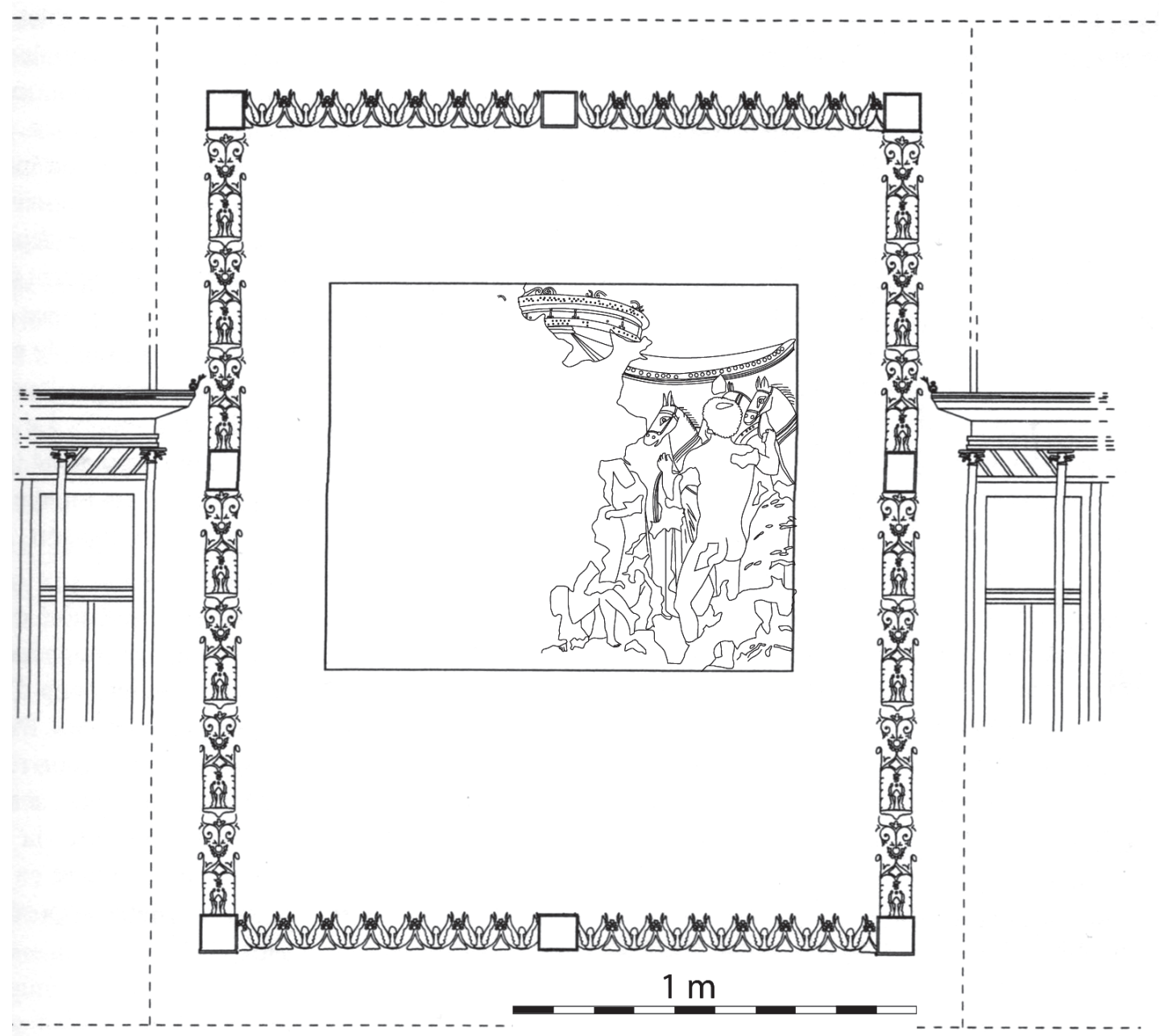

Fig. 15a. Clos de la Lombarde, Narbonne, House IV, decoration with Phaethon (reconstruction: M. et R. Sabrié).

Second Style, and of large-scale narrative painting.

The "Phaethon mural" in House IV at Narbonne's Clos de la Lombarde (fig. 15a; 15b in colour) combines old elements and new in an eclecticism characteristic of the 2nd c., full of reprisals, revivals and innovations. ${ }^{62}$ This work originally adorned the walls of a state room that were also decorated with a true marble opus sectile, indicative of the wealth of the owner. The iconographic richness of the paintings is reflected in the detailed composition of the middle zone of the walls, the centrepiece of which is a large mythological picture - a rarity for the period, even in Italy - whose composition is reminiscent of the works of the Fourth Style. ${ }^{63}$ The decorative borders in the form of architectural features adhere nonetheless to the conventions of the $2 \mathrm{nd}$ c.

The more novel trend is without doubt the renaissance of grand architectural features in trompe-l'oeil (which had also disappeared with the Second Style). In this new iteration, they

62 M. Sabrié and R. Sabrié, Le Clos de la Lombarde à Narbonne: espaces publics et privés du secteur nordest (Montagnac 2004); Sabrié and Sabrié (supra n.42) 18 and 54 with fig. 59b.

63 One of the last mythological paintings attested in Italy could be the eponymous picture in tablinum 14 of the House of Jupiter and Ganymede at Ostia (A.D. 140-150): see Falzone (supra n.36) 68-71. 
are routinely associated with large-scale narrative paintings, much larger and more spectacular than simple pictures, sometimes reaching such proportions as to cover, without a frame, an entire section of the wall. The most remarkable examples of these "megalographic" scenes date to the second half of the 2 nd and beginning of the 3rd c. ${ }^{64}$

In the middle of the 2 nd c., imitation marble was largely restricted to the lower section of the wall, in the more luxurious homes at times reaching considerable heights in the form of opus sectile (marquetry in real marble). The spectacular wall-painting of Room K in Narbonne's Maison à Portiques provides an example of a composition that clearly evokes a theatrical façade in the manner of the scenographic works of the Second and Fourth Styles. ${ }^{65}$ The novelty resides most notably in the height of the lower zone, in imitation of opus sectile (visible on the SE wall), and in the composition of the narrative picture of the central aedicula, in which two large allegorical figures (a winged victory and a Genius) are positioned where the taste of an earlier age would have preferred a mythological scene or a landscape on the SW wall. Aediculae on side walls, rendered in perspective, would have lent a pleasing effect of depth in trompe-l'oeil.

The taste for mythological scenes would not be revived until the Severan era at the turn of the 3rd c. Their revival is all the more remarkable because they took the form not of small pictures or miniatures, as before, but stunning compositions in which the figures often achieved life-size dimensions. This trend, which would last the duration of the 3rd c., is thus far best known from examples north of the Loire, in Belgica and Lugdunensis, ${ }^{66}$ but one can discern the basic elements in the paintings of room $\mathrm{K}$ at Clos de la Lombarde. Alhough this revival seems at present to be a regional phenomenon, it would be premature to exclude the provinces of Narbonensis and Aquitania definitively, as new discoveries could extend the distribution of spectacular narrative paintings of the Severan age. Caution is all the more advisable as examples of such large-scale narrative scenes with life-size figures are known in Italy in the 3 rd c. ${ }^{67}$

\section{Imagery in the wall-paintings of S Gaul}

\section{Defining the parameters of narrative wall-painting}

The images that appear in wall-paintings of S Gaul form a fairly varied repertoire drawn from the key themes of Italian painting: mythological pictures, landscapes, scenes of hunting and sport. In this respect, Gallo-Roman wall-paintings are an accurate representation of the classic repertoire. These images assume different forms on the painted wall, whether in narrative pictures and miniatures or as isolated motifs. But before proceeding, we must define what constitutes a "narrative painting". A narrative scene should combine at least two of the following elements: one or more characters, an action, and a landscape. Thus, an image comprised of a single figure, whether the figure performs an action or is situated in a landscape, constitutes a "narrative scene". We can therefore make a distinction between "narrative scenes" and isolated figures or subjects that occur outside of any narrative

Sabrié and Sabrié (supra n.37) 165.

M. Sabrié and R. Sabrié, "Les manifestations du culte impérial à travers la peinture," RANarb 32 (1999) 57-63.

66 Barbet (supra n.6) 290-91.

67 Ibid. 266. See, for instance, the paintings from Rome's Stazione Termini: cf R. Paris, Antiche stanze: un quartiere di Roma imperiale nella zona di Termini (Milan 1996). 
context: flying figures, candelabra, masks, and so on. These elements tend to appear in isolation at the centre of a panel (e.g., winged figures), as as inter-panel ornaments, or associated with architectural elements (such as resting on an entablature, a cornice, or the top of a column).

\section{Provincial images and their Italian counterparts}

Provincial wall-paintings presented an ideal medium for Greco-Roman iconographic themes. Images spread to Gaul, as to other provinces, through a number of vehicles. Among the most effective, and the oldest, are small objects on which images from the Greco-Roman repertoire appear: vases, terracotta lamps and engraved stones were all objects of commerce that circulated on a Mediterranean-wide scale. Their small size and relative value as commodities aided their diffusion. Images were transferred from one medium to another, very few being restricted to specific types of objects. ${ }^{68}$ With regard to paintings and mosaics, ateliers played an active rôle. With their first voyages to $S$ Gaul to decorate the homes of the élite at the end of the Republic, and especially with the installation of artisans at the Gallic capital of Lugdunum, where Augustus himself was established periodically between 16 and 12 B.C., or in Narbonnensis in the Augustan age, when provincial demand became particularly strong, such ateliers introduced not only the taste for pictorial décor (of the Second and Third Styles), but also an entire repertoire of images. Thus we find in Narbonensis, Aquitania and elsewhere in Gaul models and images based on the Italian repertoire.

It is impossible to avoid the question of iconographic hapaxes that might appear to be provincial idiosyncrasies. Such scenes would certainly be difficult to recognize given the fragmented nature of many of the ensembles, but at present no such scenes are known in Gallo-Roman painting that could be considered clearly to represent themes outside the Greco-Roman repertoire. At most, we can point to some rare examples of iconography which present challenges of interpretation that are not simply due to their fragmentary state of preservation. ${ }^{69}$

\section{The arrangement of images on the wall}

Art-historians conventionally divide the painting into zones that follow the horizontal subdivisions of the mural, which reflect the work pace of Roman painters and the organization of the project into "workdays" (Ital.: pontate). These three zones are the lower (socle), middle and upper (fig. 16 in colour). The wall is also divided vertically into several zones, usually three since the advent of the Second Style - but the number could vary with the wall's length. Walls could be divided vertically into 3 or 5 zones, sometimes more in the case of a peristyle or hallway, but always an odd number due to painters' tendency to organize paintings around a central panel. It is in this central panel that the most beautiful narrative scene is usually found, often emphasized by its greater relative size or by a trompe-l'oeil architectural frame (such as a faux aedicula).

68 All the studies centered on a particular iconographic theme attest to this. For example, for the images of the founding heroes of Rome see A. Dardenay, Les mythes fondateurs de Rome: images et politique dans l'Occident romain (Paris 2010); ead., Images des fondateurs: d'Énée à Romulus (Bordeaux 2012) 43-44, for a reflection on the distribution of images by supports.

69 This is the case, outside our geographical area, with an example in Reims at rue Libergier: A. Balmelle, "Enduits peints à Reims (Marne): découvertes anciennes et récentes," in La peinture romaine dans les provinces du Nord (Actes du XIe séminaire de l'AFPMA, 1988) (Amiens 1990) 13-25. 
In the lower zone, the organization of narrative scenes in friezes predominates. This type of frieze served as a transition between the lower and central zones, particularly to mask the divisions between two "workdays". The subjects are arranged either in a continuous frieze or within a succession of compartments. A chronological trend can be discerned with regard to their composition. Continuous friezes are characteristic of the 1st c. B.C., with examples preserved at Fréjus, Nîmes, Vaison-la-Romaine and Aix-en-Provence (figs. 6-7). ${ }^{70}$ The known examples suggest that this decorative convention was particularly favoured in Narbonensis. ${ }^{71}$. They are generally friezes of small figures performing human activities against a black background. Only the tone changes: at Aix-en-Provence there are hunting cupids, while at Nîmes dwarfs parody mythological scenes. Numerous parallels can be found in Italy: for the frieze at Nîmes there is an example on a black background in Pompeii's Casa del Chirurgo where dwarfs re-enact the judgment of Solomon, while the cupids on the predella at Aix reflect one of the most popular Italian themes, the activities of Cupid. ${ }^{72}$ Narrative friezes below the central zone, in predellae, become rarer after the 1st c. ${ }^{73}$ Stylistically, the predominance of this type of composition in the 1st c. is unsurprising. Narrative friezes (continuous or compartmentalized) in this position are characteristic of the Third and Fourth Styles, and their presence on Gallo-Roman walls is but one of many elements indicative of the adoption of Italian decorative conventions.

The middle zone, set at eye-level, constitutes a privileged space for the development of more elaborate motifs, such as narrative scenes. The presence of pictures or miniatures in the middle zone is, with some few exceptions (see below), a stylistic trait typical of the 1st c. A.D. In these compositions, which alternate panels and inter-panel motifs in the middle zone, the pictures are generally depicted as being suspended in the middle of the panels, to produce the effect of an easel painting hung on the wall. The effect of pinakes suspended by a thin line is evident on a wall at Vaise, near Lyon, ${ }^{74}$ where wooden shutters painstakingly painted in trompe-l'œil 'protect' small still-life pictures (figs. 17a-b in colour). A representative example of this type of wall-painting can be found at Périgueux in a panelled composition bordered with garlands and pearls that bears miniature pictures in the central panel (fig. 6). These small pictures, heavily altered today, may have represented a series of still-lifes on a white background, in the same manner as at Vaise.

This type of spatial organization of narrative scenes in wall-painting conforms perfectly to the stylistic conventions of the Third and Fourth Styles that were developed in Italy during the 1st c. A.D. and then spread ${ }^{75}$ to Gaul. The preserved examples are too fragmented or too rare to provide an indication of the kinds of themes that would have been presented in them, but some restored examples allow us to suggest that myths and epics

70 Fréjus, place Formigé, pièce U: see A. Barbet, G. Becq and F. Monier, La peinture romaine: fresques de jardin et autres décors de Fréjus (Fréjus 2000); Barbet (supra n.6) 74-76. Nîmes, Villa Roma, maison 10, pièce 2: Vaison-la-Romaine, La Villasse, Maison des animaux sauvages, pièce à la mosaïque de perdrix: J. Sautel, Vaison dans l'antiquité (Avignon 1942) pl. XXXV. This type of frieze is much more rare in decoration in other provinces: Dardenay (supra n.59) 346-51.

72 To obtain an idea of the importance of this iconographic corpus, see LIMC III, s.v. Eros/Amor, Cupido (N. Blanc and F. Gury).

73 We should also mention the scenes of munera from La Croisille-sur-Briance: F. Dumasy, La villa du Liégeaud et ses peintures: La Croisille-sur-Briance (Haute-Vienne) (Paris 1991). 
would have formed the basis of popular subjects for paintings of this period. We refer to the iconographic themes of Room 2 in House 10 at Villa Roma in Nîmes (fig. 7). Dated to the middle of the 1st c. B.C., the frieze with a parody referred to earlier is associated with pictures set at the centre of the panels in the middle zone; the only one preserved depicts a young god or hero, nude, seated before an architectural background, the composition being precisely in line with mythological pictures of the Fourth Style in Campania. A similar iconographic scheme is represented by the painting from Pompeii's Casa del Centauro (MANN 8980) depicting Meleager, where the representation of the hero is comparable to that at Nîmes: against an architectural backdrop, a young nude hero sits on stone blocks in the foreground. At Pompeii he wears a red mantle, at Nîmes a white one which enfolds his waist without hiding his nudity entirely. Armed with a lance, he should be a hunter or warrior, as were most heroes. At Pompeii, we can further identify the young man as Meleager from the figures that surround him: the boar lying at his feet and the young woman dressed for the hunt who converses with him provide the key, so that the young woman must be Atlanta who was also tracking the boar at Calydon and dealt the first blow that Meleager was supposed to wield (it was during that hunt that the two fell in love). In a picture from Herculaneum (MANN 9245), the young hunter in the foreground is again seated on large stone blocks but hunched over, holding two lances, as did Meleager in the Pompeian picture. A female figure again provides the key to his identification, in this case Selene (recognizable by the luminous crescent surrounding her head) in an amorous encounter evoked by a cupid in flight at the center of the picture. These elements allow us to identify the young, sleeping hero as Endymion. Selene subsequently entreated Zeus to keep him in his sleeping state, thereby preserving his beauty. In much the same tradition is the Polyphemus of Herculaneum (MANN 8984), though here the young ephebe is replaced with a monstrous lover. In short, the composition of a young hero seated on a block or on rocks (or on a chair) was commonly used in multiple images to represent several different mythological figures. All of these young men, with idealized physiques and the trappings of a hunter or warrior, strongly resemble one another, such that it is often only the narrative context (the female figure, some animals, some aspects of the landscape or an occasional inscription) that allows us to identify them. At Nîmes, the scene and the primary figure provide no precise clue. Evidently the patron or the painter decided to allude to the mythical universe, parodied in the frieze that runs beneath in the predella, without specifying a particular hero. An alternative composition has the hero or a ruler seated on a chair or throne rather than on blocks of stone. It is this theme that was adopted in a scene in the black frieze at Herculaneum ${ }^{76}$ and in the panel featuring a 'royal couple' at Boscoreale, ${ }^{77}$ where once again the young man has his head turned toward the young woman standing at his side. Painters no doubt generally worked from memory on the basis of a limited number of formulas and compositions that they adapted as needed to suit the subject. That would explain the repetitions and wide diffusion of these kinds of images, which are at times a little stereotypical.

The vast majority of these compositions are pictures placed in the middle zone in works of the 1st c. B.C., but some date to the 2 nd c. A.D. Such is the case with the paintings

76 Known as "Pinakes with dionysiac scenes": Musée du Louvre, P 27 (NIII 3073) Tran (supra n.15) 51-54.

77 Cf M. Grimaldi, “La villa de Publius Fannius Synistor et le Pagus Felix Suburbanus,” La villa romaine de Boscoreale et ses fresques, vol. II. Actes du colloque 2010 (Paris 2013) 76. 
discovered at Brachaud and Bon-Encontre (Aquitania). ${ }^{78}$ At Bon-Encontre (fig. 14), the pictures are placed at the centre of the panels against a white background, separated by stalks of foliage. The pictures from the baths at the Brachaud villa were likewise painted against a white background. In both cases, the paintings are so poorly preserved that the figures cannot be identified with any precision. The fact that the few known examples come from the west of Gaul is probably a coincidence of preservation, since similar examples can be found in panel paintings as far away as Brigetio in Pannonia. Although the white backgrounds are perfectly in keeping with the aesthetic of the 2 nd c., the pictures belong to a pictorial tradition inherited from the preceding century. They depart from paintings of the 2nd c. in Italy in that the preserved fragments indicate a disinterest in narrative scenes, especially those of a mythological nature; where such themes do persist, they are no longer emphasized in the central panel, but relegated to secondary positions.

Does the persistence of panel paintings in the western provinces point to a relative independence from Italic models? Rather than independence, I would argue that these patterns constitute an eclecticism in which the pictorial traditions of the 1st c. B.C. were constantly being revitalized by new decorative motifs arriving from Italy. ${ }^{79}$

The Phaethon mural at House IV at Clos de la Lombarde appears as a rarity, but it is roughly comparable to compositions in Italy of the 2nd c. Particularly striking is the presence in the central panel (figs. 15a-b) of a large mythological picture framed by architectural elements, an arrangement inherited from the Fourth Style which did not have wide influence in Gaul. The left section is missing but one can discern in the foreground a young heroic nude, viewed from behind, driving a team of horses. On his head he wears wings that symbolize his affinity with elements of the sky. On the basis of comparisons, it has been proposed that this is Phaethon asking permission from his father Apollo to drive the chariot of the Sun (alas, his celestial aspirations proved fatal). The Phaethon mural belongs to a moment (the 2nd c.) when in Italy the mythological picture in the middle zone was experiencing a decline. In the vicinity of Rome, pictures as framed subjects seem to disappear from wall-painting around A.D. 150. One of the latest examples might be Ostia's Domus di Iove e Ganimede. That is rather similar in composition to our Phaethon, with architectural elements on either side of the central panel framing the picture of Jupiter and Ganymede. ${ }^{80}$ After this date, in Italy human and animal figures are still portrayed but without a setting or context, often shown suspended against the background. Narrative scenes are unframed. When they are central to the composition, they often cover an entire wall or even an entire room.

Nonetheless, with respect to the eclecticism that characterizes Gallo-Roman painting of the 2nd c., as a general rule, and in keeping with what can be observed as occurring in Italy, narrative scenes seem to fall out of favour. ${ }^{81}$ Interest in mythological scenes seems not to have revived until the Severan period. Figurative motifs assumed a secondary form

Villa de Brachaud, room S1: J.-P. Loustaud, "Les thermes de la villa gallo-romaine de Brachaud (Haute-Vienne)," Travaux Archéologie Limousine 3 (1982) 31-52. Bon-Encontre, villa de SainteRadegonde: Barbet (supra n.6) 235. Vieux, Le Bas-de-Vieux, maison au Petit Péristyle, room II: P. Vipard, La maison du "Bas de Vieux": une riche habitation romaine du quartier des thermes d'“Aregenua" (Vieux, Calvados) (Caen 1998) 88 (drawing by B. Amadei).

79 Baldassarre, Pontrandolfo Greco and Rouveret (supra n.24) 323.

80 Ling (supra n.1), fig. 191.

81 Baldassarre, Pontrandolfo Greco and Rouveret (supra n.24) 279 and 323. 
compared to the pictures and miniatures that had been given pride of place in central panels, but they are no less spectacular in terms of detail and execution. Isolated figures of smaller size often adorn the lateral panels, especially when the central panel is dedicated to a picture.

Over the course of the 1st c., a concomitant taste developed in the centre of painted walls for flying figures, both human and animal, and for vignettes. This type of mythological vignette can be found in Gaul, such as the cupids at Plassac and Vaison: at the former, a cupid driving a team of dolphins ornaments a black background, ${ }^{82}$ while at the latter cupids float on panels with red backgrounds (fig. 8 above). Medallions are another common element in the central zone. Often they bear the busts of deities, mythological beings or portraits. In some cases, as in the series of medallions from the exedra in the Casa del Atrio a Mosaico at Herculaneum, ${ }^{83}$ the genres seem to merge. It seems that the inventiveness of painters and their taste for fantasy led them sometimes to represent their subjects (the members of the family most often, one would suppose) as mythological figures. This would explain the strong impression of familiarity and the intensity of expression that are so evident in these smaller works. Medallions can also be found in the upper zone, as at Plassac, and even in the lower zone. ${ }^{84}$

\section{Inter-panel candelabra motifs}

Candelabra and floral variations of such are the preferred structural element of painters in Gaul from about the turn of the era to c.A.D. 140. Painters turned increasingly toward objects and subjects (notably birds and animals) depicted in a vacuum, in a style that culminated at the end of the 1st c. A.D. (fig. 9). The use of the candelabrum to subdivide the surface vertically first appeared in Italy, but it had an independent trajectory of development in Gaul (notably, also in Germania). It proved a great source of inspiration for painters, to whom it apparently offered greater freedom of expression than did other zones of the wall. In Gaul, the candelabrum lost its central post or upright in many cases when it was replaced with vertical stacks of various items (vases, birds, etc). Certain themes seem to have found particular success and were repeated, imitated and adapted. Examples include pairs of opposing swans (Orange) and leaping dolphins (Roquelaure). A larger figure generally crowned this vertical arrangement, as at Saint-Romain-en-Gal (fig. 9). These iterations bear little resemblance to the original 'candelabrum' and logically should have lost that name, but the decorative rôle of providing a vertical separation between two panels was maintained, and a clear relationship to traditional candelabra is evident. At the start of the 2nd c., the candelabrum was more and more densely populated, almost always presented against a black background and related to an animated frieze on a similar background, as at Croisille-sur-Briance, ${ }^{85}$ but by mid-century, when it was transformed into a stalk of foliage, the umbellae and items disappeared, as at Bon Encontre (fig. 14), Gémenos

82 M.-O. Savarit, "Les peintures murales romaines de Plassac (Gironde)," Peinture murale en Gaule. Actes du séminaire AFPMA (Oxford 1985) 113-35; M.-O. Savarit, "Les peintures murales de la villa gallo-romaine de Plassac," Actes XXXVIe Congrès d'Etudes régionales, Blaye 1984 (Bordeaux 1988) 21-30; A. Barbet and M.-O. Savarit, Peinture murale romaine en Gironde (expo, Bordeaux 1983) 31-32.

83 A. Dardenay, "Herculanum. Voisine oubliée de Pompéi," Archéologia n 508 (2013) 30-45.

84 See Bordeaux, allées de Tourny: Barbet and Savarit (supra n.82) 21; Barbet (supra n.6) 230-31, fig. 562.

85 Dumasy (supra n.73). 
or villa Grassi.

Whereas the central zone was generally viewed as the most privileged space for narrative scenes, and its position at eye level made it the most clearly visible area of the wall, the upper zone, less directly visible, was rarely decorated with figurative scenes. In the few exceptions that have been documented, these scenes took the form of friezes, not pictures, as they did in the lower zone, and further similarities are apparent in the decorative themes preferred. At Aix-en-Provence, the frieze of gladiators painted against a red background (fig. 18 in colour) is dated to the 1st c., but examples from other Gallic sites (such as Beaumont-sur-Oise ${ }^{86}$ ) demonstrate that figurative friezes in the upper zone persisted as late as the 3rd c. Medallions have also been documented in the upper zone, as at Plassac, dating to the middle of the 1st c. One bears a head of Medusa, the other a bearded deity. Similarities with a painted medallion documented at Allées-de-Tourny (Bordeaux), dated to the 2nd c., and comparisons with the example at Plassac, serve to illustrate both the persistence of certain images and the evolution of decorative styles. One explanation for the scarcity of motifs in the upper zone (with the exception of examples in Narbonensis which adhered more closely to Italian models) is simply the preferred treatment of this zone by most Gallo-Roman painters.

\section{Ceiling decorations}

Although poorly known because generally less well preserved, painted or stuccoed ceilings were a crucial component of a room's decoration, indeed the crowning element of the decorative ensemble. The ceiling often echoed the themes of the wall-paintings and the floor mosaics: there was often a sort of 'mirror effect' between ceiling and floor. ${ }^{87}$ While geometric and gridded or latticework motifs were dominant in ceiling decoration, figurative designs are also documented. The central decorative element was usually the culminating point of a composition. In particularly luxurious cases, an enduring approach was to position a large figurative painting at the centre of the ceiling composition, often within a medallion, hexagon or another geometric form, and to organize the rest of the decorative motif(s) around the central figure. A splendid example is preserved at Clos de la Lombarde in Narbonne (fig. 19 in colour), where a maenad appears to hover over the floor ${ }^{88}$ In the borders and in the concentric bands that often surrounded the central motif, figurative miniatures can sometimes be found, as in Narbonne's House III, in which a landscape is framed within a lozenge. With its blend of architecture and foliage in a very light palette, this painting, although dated to the 2nd c., is in the tradition of the sacroidyllic landcapes of the 1st c. A.D.

The preferred themes in the wall-paintings of S Gaul

(a) Mythological subjects

Greco-Roman mythology served as inspiration for provincial painters and their patrons, who drew quite readily from this vast repertoire. Generally speaking, iconographic conventions were respected, including the details of the pictures and the attributes of specific

H. Eristov, C. Kohlmayer and D. Vermeersch, “Beaumont-sur-Oise (95): l'habitat du IIIe siècle et son décor peint au sud du cimetière, zone 18," RACentre 41 (2002) 187-224.

87 Barbet (supra n.6) 315-42.

88 Demore and Sabrié (supra n.43) 93, n 51b. Sabrié and Sabrié (supra n.42) 18 and 54 with fig. $59 \mathrm{~b}$. 
figures. As long as the paintings are sufficiently preserved, the images are easily identifiable. With regard to preferences for specific themes, just as in Italy figures of love (eros or cupid) as well as those connected with Dionysus (including members of his thiasos: maenads, satyrs, etc.) were widely favoured. We cite, notable for its precocity, the Bacchus of Roquelaure, ${ }^{89}$ identifiable on the basis of his thyrsus, much like a figure of Bacchus against a blue background from Herculaneum (MANN, inv. 9277). The world of Dionysus, evoking wine, celebration, festivities and pleasures, was perfectly suited to the décor of triclinia, which, as the principal spaces of entertainment, were the most richly decorated (and thus likely to contain many figures).

(b) Landscape paintings

Long considered a genre born in Roman contexts, the landscape is now known to have Greek origins, notably in the form of backdrops to mythological scenes. ${ }^{90}$ Nonetheless, it was Italian painters who elevated the landscape to a genre unto itself. At the end of the Republic, monochromatic landscapes enjoyed a popularity that would have a lasting effect. The landscapes painted in shades of yellow in the Villa of P. Fannius Synistor at Boscoreale $^{91}$ and the Villa of Poppaea at Oplontis, and even in the upper-zone friezes of an exedra in the 'House of Livia' on the Palatine, must have inspired compositions like the one discovered in a late-Republican house in Vieille-Toulouse. ${ }^{92}$ Contemporaneous with the Italian examples, that monochrome landscape was painted in a superb cinnabar-red, further indication of the wealth of the patron. The Italian conventions have been respected, such as the small detail of the figure standing on the bridge who is present on several of the Campanian examples. Amongst Roman landscapes, "sacro-idyllic" landscapes hold a special place, if only for the level of popularity they enjoyed well after their emergence in the Augustan age. These somewhat impressionistic landscapes, in which architecture, aquatic animals and plants, and terrestrial foliage blend together, are a Roman invention with their omnipresent sanctuaries and deities (human figures, if present at all, appear only as anonymous silhouettes). According to Pliny (NH 35.16), Studius at the court of Augustus excelled in this genre of painting. In Aquitaine, there is a fine example among the miniatures at Allées-de-Tourny, Bordeaux. ${ }^{93}$

(c) Hunting and sport

A small number of preserved murals depict scenes of hunting or gladiatorial combat, even though they were popular in mosaics, reliefs and terracotta lamps. When scenes of this kind do occur in wall-paintings, they are generally relegated to the friezes painted below (as predellae) or above the central zone. In some cases, hunting scenes take on a mythological tone, setting the scene for cupids. Some attractive examples of the latter are preserved at Aix-en-Provence and in the peristyle of Herculaneum's Casa dei Cervi. Scenes of gladiatorial combat are most often relegated to friezes but, unlike the hunting scenes, are usually realistic in tone, as at Aix-en-Provence (fig. 18). The painter often took pains to render the armour and weapons of the combattants in detail. Duels between gladiators are

89 Barbet (supra n.23); Dardenay and Gardes (supra n.24).

90 J.-M. Croisille, La peinture romaine (Paris 2005) 204.

91 Metropolitan Museum of Art, cubiculum M: Bergmann (supra n.15) fig. 57.

92 P. Capus and A. Dardenay, L'empire de la couleur: de Pompéi au sud des Gaules (cat. expo, Toulouse 2014), p.147.

93 Barbet and Savarit (supra n.82); Barbet (supra n.6) fig. 104. 
shown, as well as venationes pitting gladiators against wild animals. Two paintings from Périgueux (fig. 20 in colour) depicting gladiatorial combats are uncommon with regard to both their size and the places they occupy within their compositions. At "Terrain de Lestrade", the combat scenes are set in the central zone, at eye level, and staged on at least two registers. The examples at the "Domus des Bouquets" 94 stand out in terms of the sheer size of the human figures. At both sites, the detailed and realistic garments and weapons of the gladiators are worthy of note. The painters took care to render each material in a distinct colour: yellow for bronze, brown for leather, blue for iron. This, in addition to the dynamism of the human forms and the anecdotal nature? of certain depictions, lends a remarkably lifelike quality to the paintings. In the same spirit of realism, the names of the gladiators were inscribed close to their likenesses in both of the Périgueux examples. There are also two fragmentary lines of inscription, the surviving text suggesting that this was a dedication naming the sponsor of the games and the occasion on which they were offered. Such acts of generosity were obligatory for those who aspired to high office in the administration or governance of their cities. There are many examples of paintings commemorating these kinds of grand public gestures, and the paintings in Aquitaine were probably painted with the same intent.

\section{The world of the theatre}

Echoes of the world of the theatre radiate through the scenography of the Second Style (1st c. B.C.) and the architectural compositions of the second half of the 2nd c. A.D. In composing paintings like those at the villa of P. Fannius Synistor or at Roquelaure, painters drew on the architecture of stage-settings in theatres. The world of the theatre is also evoked in the tragic and comic masks that recur in paintings, masks seen sitting atop architectural elements such as cornices or suspended from garlands, as in the upper zone of a 2nd-c. painting at Room $Q$ at Clos de la Lombarde. ${ }^{95}$ Like masks, the tympanon, present in the paintings at Narbonne, is specifically associated with theatrical productions and would have evoked the musical numbers accompanying theatrical performances. Though not strictly limited to triclinia, paintings inspired by plays are common in those rooms. Because the triclinium was generally the chief room for the reception of guests, it was also the space in which the most investment was made in terms of displaying the host's wealth and taste. The Gallo-Roman aristocracy had an insatiable appetite for the trappings of Greco-Roman culture. Patrons decorated the walls of public spaces in their houses with pictures conveying themes drawn from the arts and literature that would demonstrate their own refinement and education to their clients and friends. It is in this context that the mural of the Phaethon room at Narbonne is best understood.

\section{Religious and professional activities: popular painting}

Whether in Italy, Gaul or elsewhere, artists did not uniformly adopt all the forms inherited from Greek idealized canons. R. Bianchi Bandinelli was one of the first to identify these lexical differences, ${ }^{96}$ proposing two contrasting modes of representation: an aristocratic mode drawing on Greek models, and a plebeian or popular mode that was decidedly more realistic. Following T. Hölscher, we prefer a more syntactic reading, attributing stylistic

A. Barbet et al., La peinture romaine. Fresques de gladiateurs à Périgueux (Périgueux 1999).

A. Bardot et al., La maison au grand triclinium du Clos de la Lombarde à Narbonne (Montagnac 2011); Sabrié and Sabrié (supra n.42) 18 and 54.

R. Bianchi Bandinelli, Rome, le centre du pouvoir (Paris 1969). 
distinctions to differences in the subject matter itself. While mythological scenes were more readily drawn from the Greek artistic tradition, this was not the case with scenes of daily life, such as family scenes or professional activities. In both Italy and the provinces, there existed a tradition in which the eschewal of realism was an aesthetic choice, rather than the default approach adopted by unskilled artisans. It was not the obligatory norm to follow Greek canons of proportion, style, perspective and iconography. Painters were mostly capable of shifting between styles and techniques as the theme demanded, a fact that reveals the rôle of genre in their artistic language. Ultimately, the stylistic formula selected was chosen according to the scene to be depicted, not according to the social status of the patron. The paintings at Castres (fig. 21 in colour) belong to popular painting that represents professional activities, in this case fullers at work. The stylistic form adopted is the same as seen at Pompeii, where paintings on exteriors might be emblematic of the activities or trades practiced within. ${ }^{97}$ It is quite possible that the paintings at Gourjade (Castres) had a similar function. ${ }^{98}$ We find the same stylistic features of popular art in narrative scenes at Loubers that depict a religious ceremony. ${ }^{99}$ The same may be said of scenes from the villa of Brachaud ${ }^{100}$ where, even if the surviving fragments have left few clues as to the activities once depicted, the realistic rendering of the surviving faces strongly suggests that the scene was inspired by daily life, not mythology.

We would emphasize the thematic coherence often visible among the images selected to decorate domestic spaces. The images in a single room are often united by a common narrative thread, especially when the walls are of the 'picture gallery' type, with multiple pictures and miniatures. In a triclinium, the pictures could have served as conversation pieces. For a group gathered at a table for a meal, the atmosphere created by the scenes of heroic tales might inspire conversation on the topics of courage, heroism or strength.

\section{Conclusion}

A striking diversity of subjects is present in the paintings of southern Gaul. Only rarely does the same scene occur more than once, even in the case of the most popular and widely diffused mythological themes. Compared to the other Gallic provinces, Narbonensis offers the greatest diversity of mythological themes, as well as the most original compositions. Generally speaking, in the evolution of its decorative schemes wall-painting in Narbonensis provides evidence for ongoing exchange between the province and Italy. The strong cultural and economic ties explain the richness and diversity of ornamental motifs, images and mythological scenes in this particular province. One notes especially Nîmes' villa Roma, House 8, in which the frieze parodies a mythological repertoire rendered in a more classical style in the central zone; viewers and patrons must have been amused by the contrast between the moods of the two, one reverent, the other comical. Fidelity to the canons of painting in Italy did not dampen a strong originality that was often based on the deconstruction and reconstruction, in new forms and according to a new grammar, of the basic

97 S. A. Curuni et al., Pompei: Via dell'Abbondanza: ricerche, restauri e nuove tecnologie (Milan 2007).

98 A. Dardenay, "Un rare témoignage iconographique: les foulons de la Gourjade à Castres," in E. Boube, A. Bouet and F. Colleoni (edd.), De Romeà Lugdunum des Convènes (Ausonius Mémoires 35; Aquitania Suppl. 31, 2014) 383-94.

99 A. Barbet and G. Becq, "La peinture à sujets figurés dans les temples de tradition indigène en Gaule," in C. Goudineau et al., Les sanctuaires de tradition indigène en Gaule romaine (Clamecy 1994) 104-14. 
A. Dardenay

elements of Roman wall-painting. This originality also took on a temporal dimension in the refusal to adopt certain pictorial modes immediately, only to do so half a century or a century later. The question of the timing of such changes is of paramount importance: the chronology of wall-painting in S Gaul is not the same as that of Italy. The relationship between the two is characterized sometimes by contemporaneity, when a motif such as an embroidered border or an architectural element passes immediately from Rome to Narbonensis, sometimes by a kind of development, as when a motif such as the candelabrum was taken up and altered well beyond its Italian forms, and sometimes by a kind of echo, as when an Italian style is re-appropriated decades later, as in the case of the wallpaper patterns.

adardenay@yahoo.fr Université de Toulouse-Jean Jaurès, CNRS-TRACES (UMR 5608) 


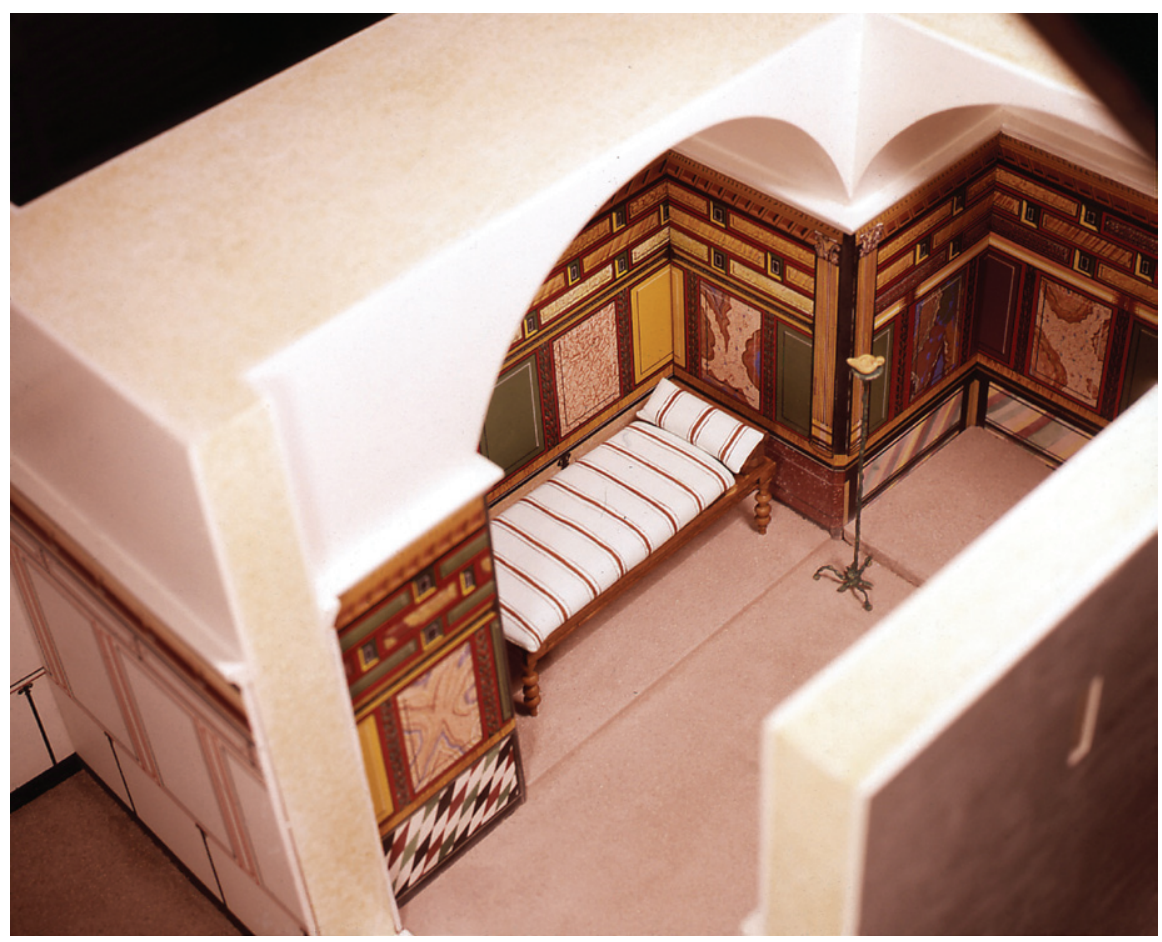

Fig. 3a. Glanum, model of the Maison aux deux Alcôves (photo: A. Barbet).

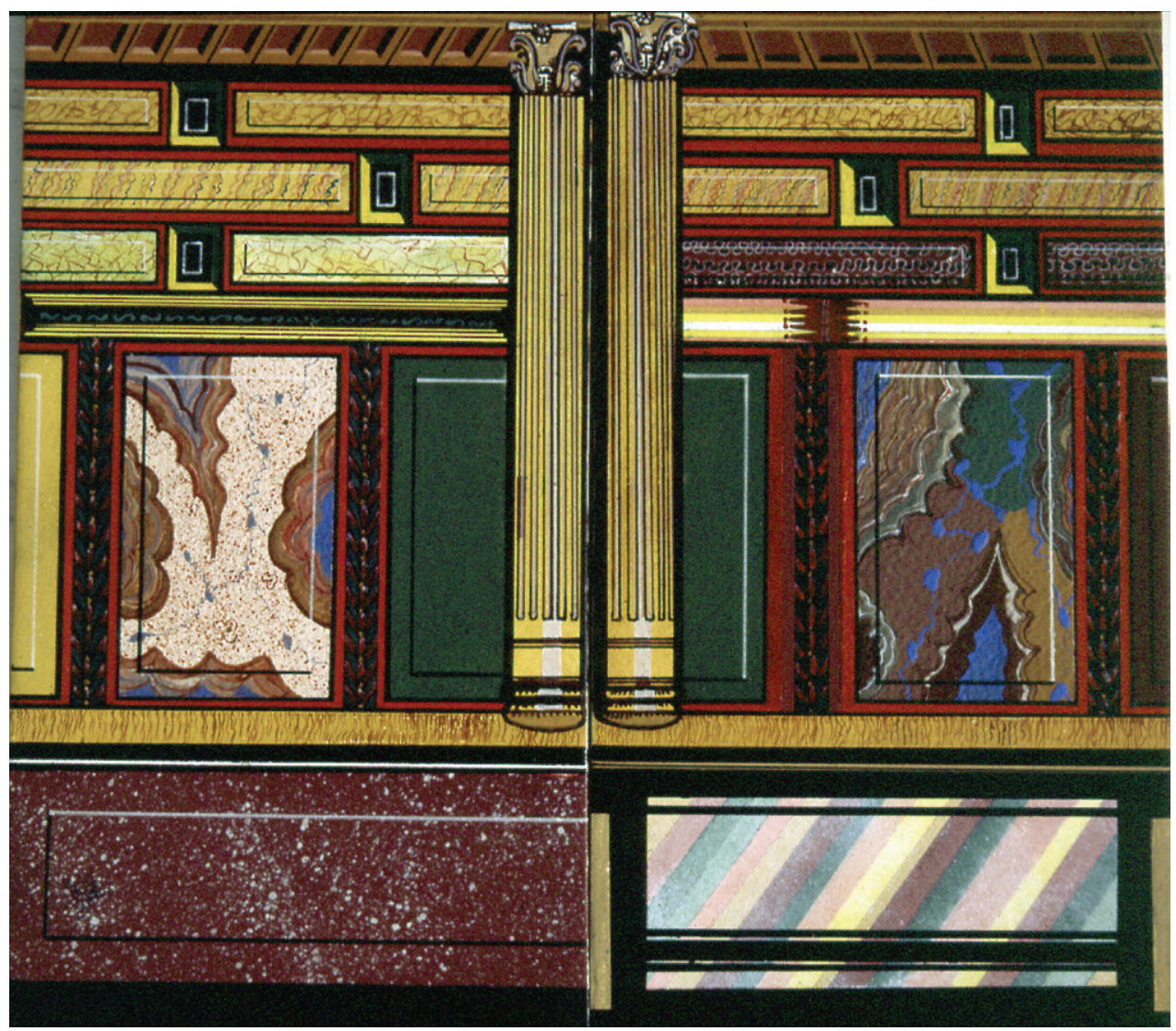

Fig. 3b. Glanum, detail of the Maison aux deux Alcôves (photo A. Barbet). 


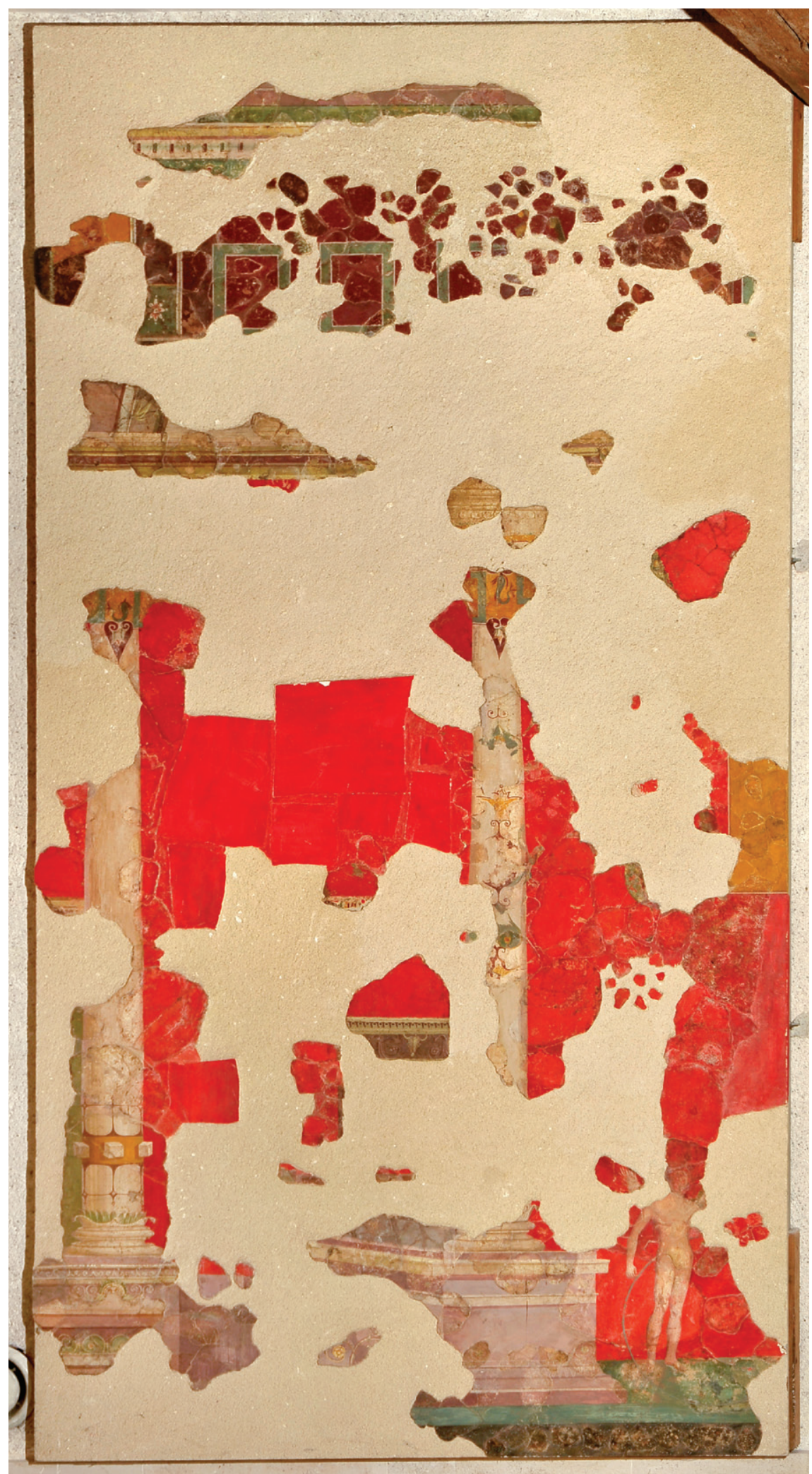

Fig. 4a. Roquelaure, detail of "décor A" (photo: J. F. Peiré). 


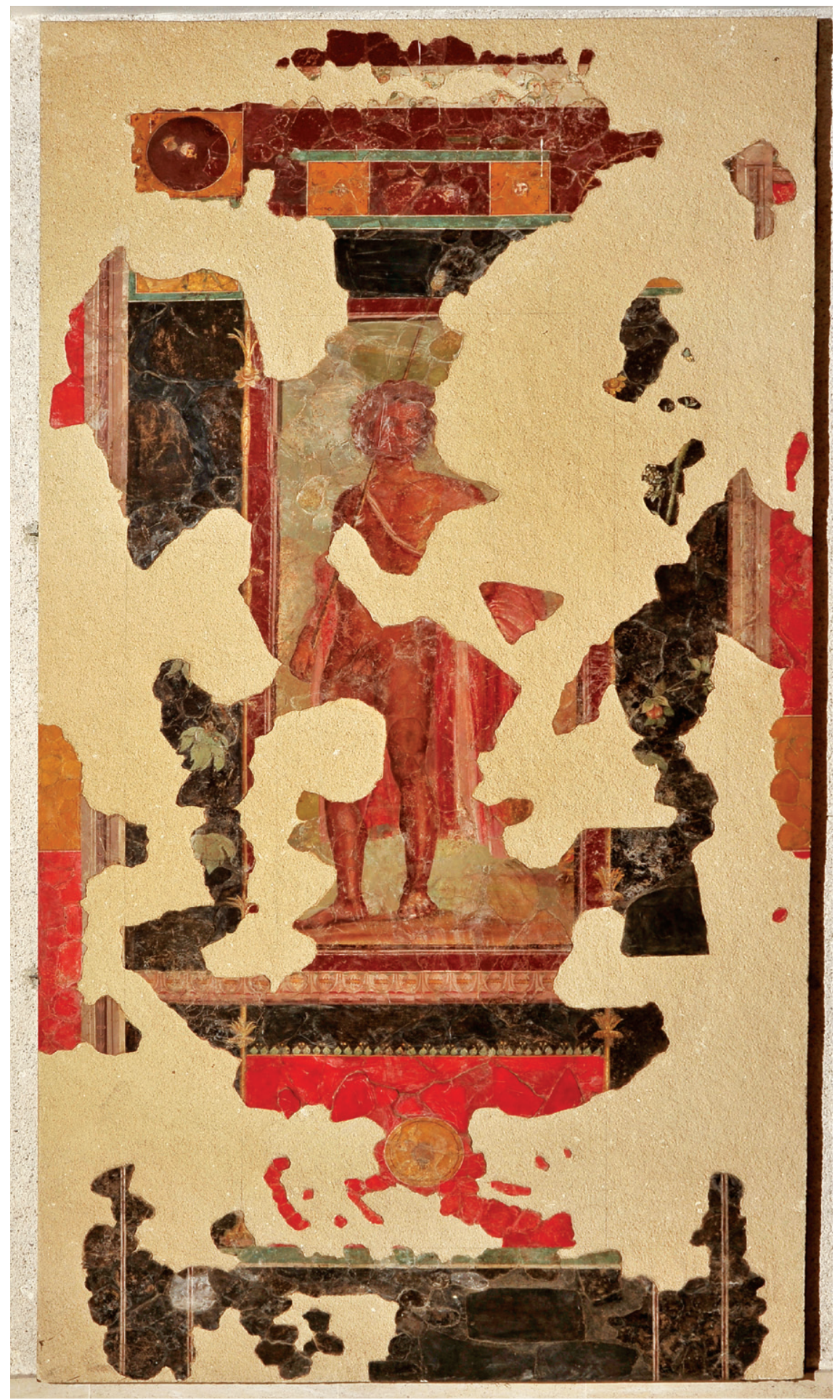

Fig. 4b. Roquelaure, détail of Dionysus panel (photo: J. F. Peiré). 
Périgueux, domus de Vésone

Décor de guirlandes à effet de perlage, paroi $\mathrm{A}$.

Restitution infographique: Jean-François Lefèvre

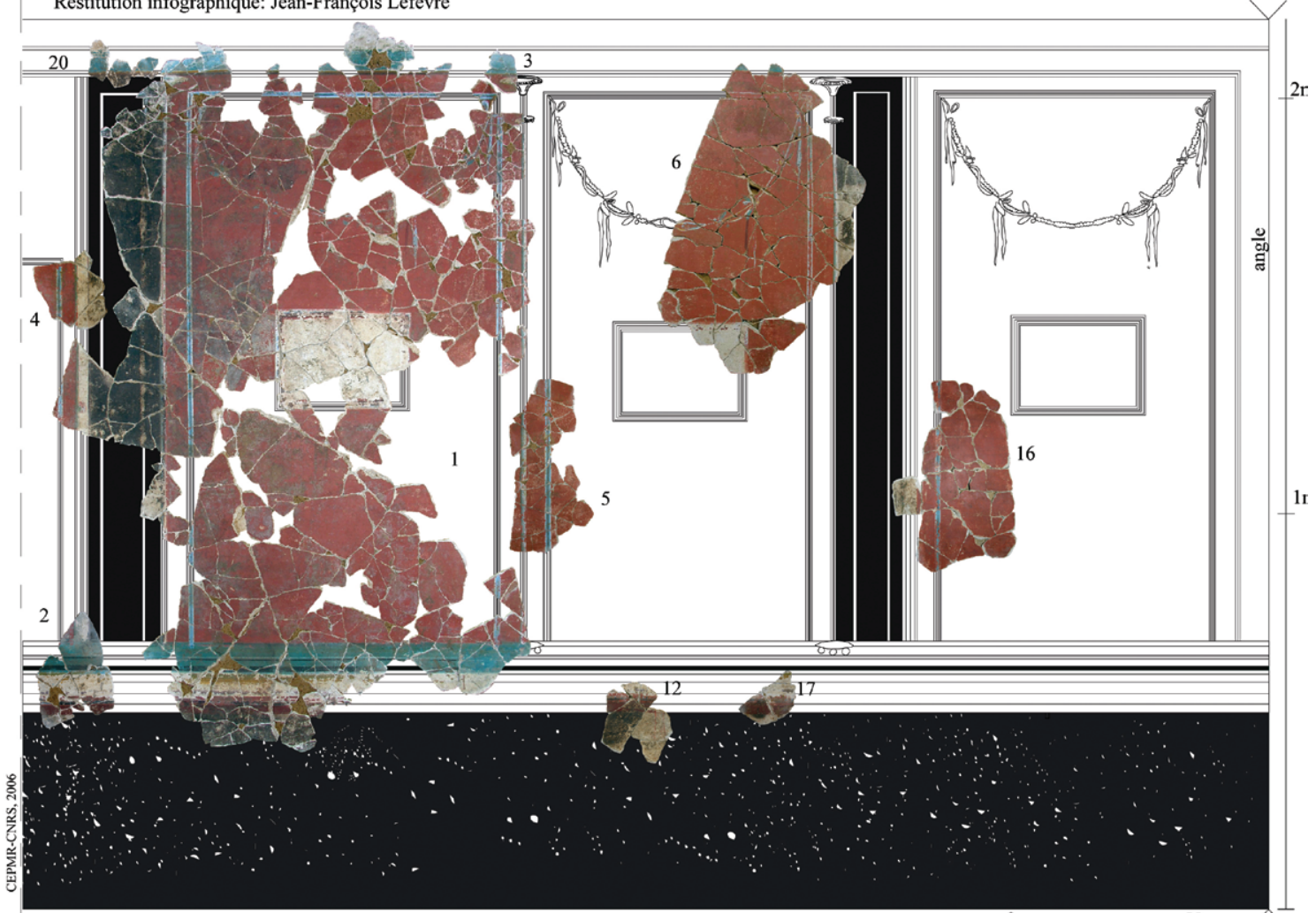

Fig. 6. Périgueux, house of Vesunna (DAO: CEPMR).

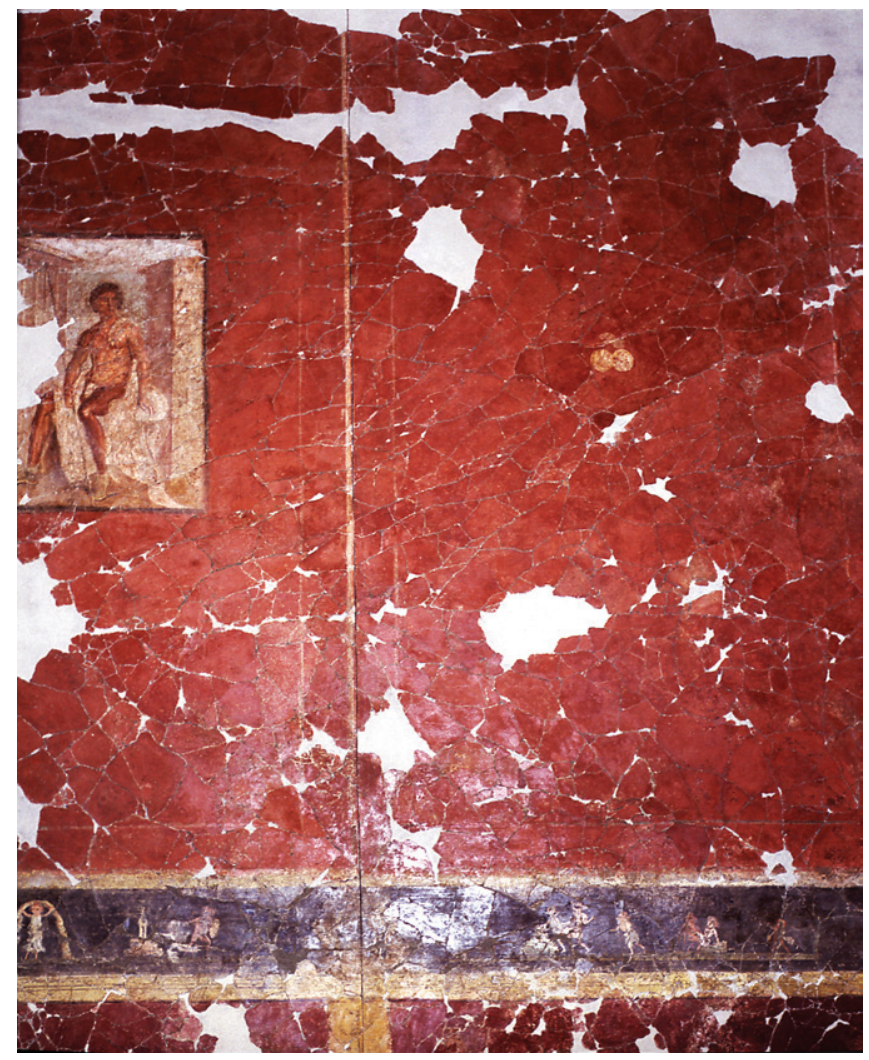

Fig. 7. Nîmes, villa Roma (photo: R. Sabrié). 


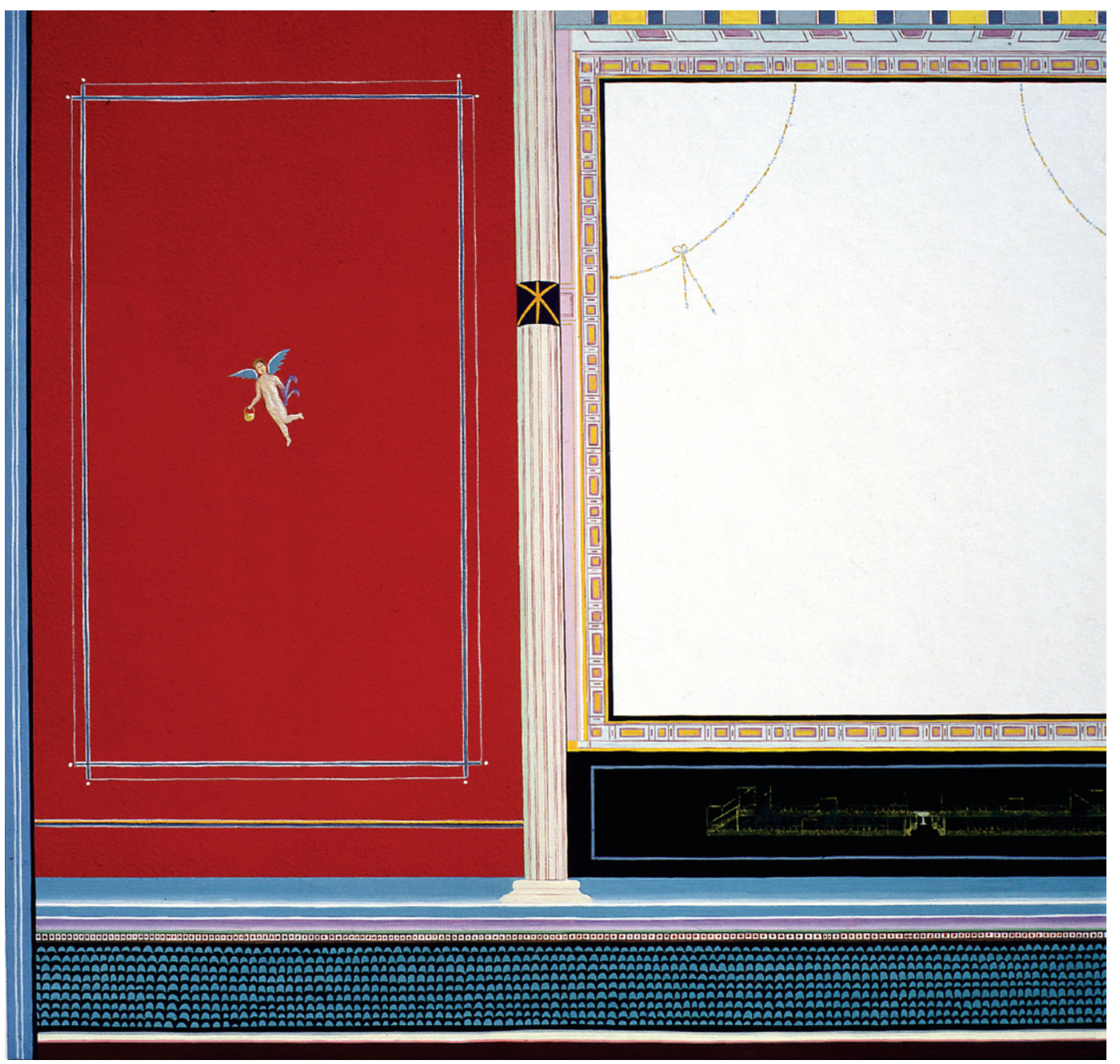

Fig. 8. Vaison-la-Romaine, house north of the Cathedral (reconstruction: A. Barbet).

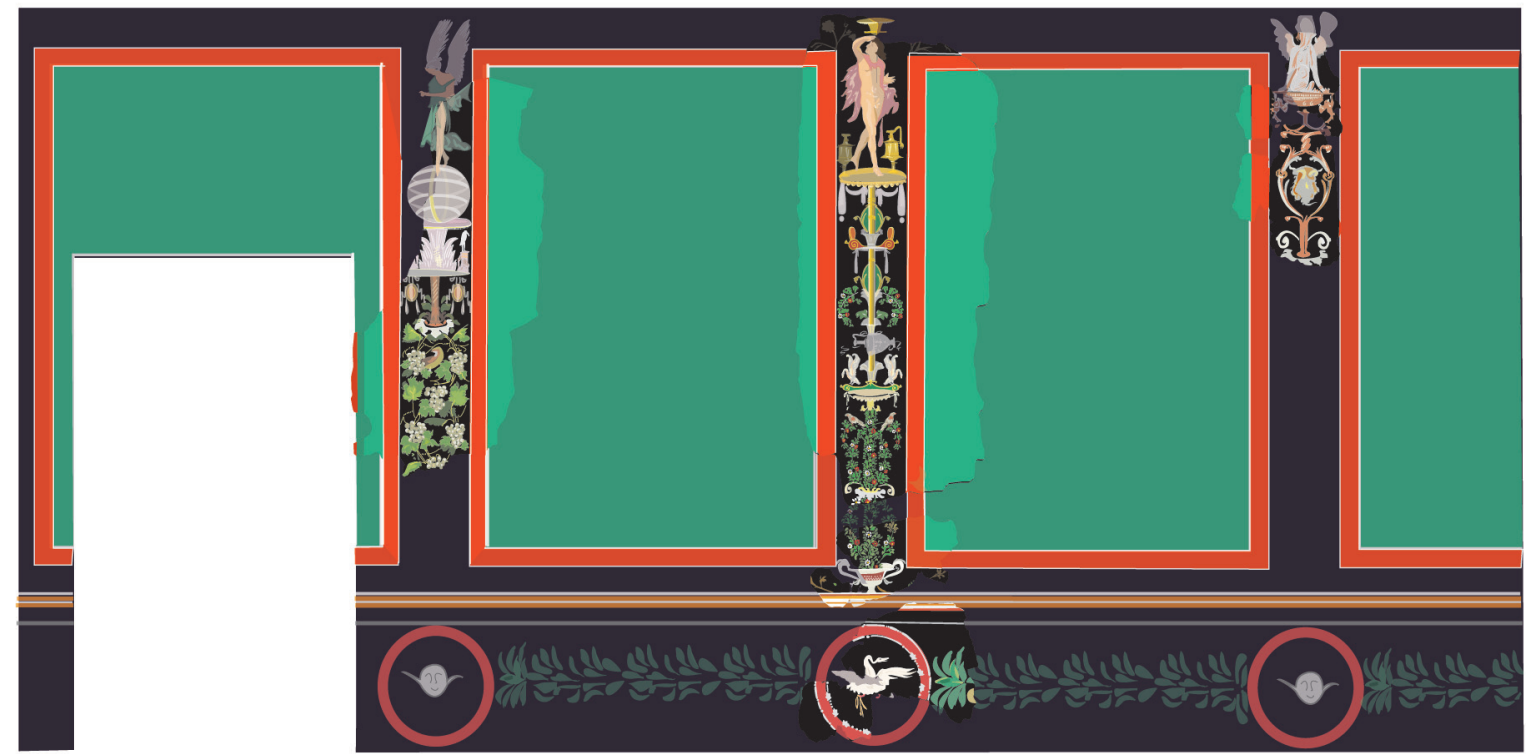

Fig. 9. Saint-Romain-en-Gal (Vienne), "Paroi du globe" (DAO: O. Leblanc). 


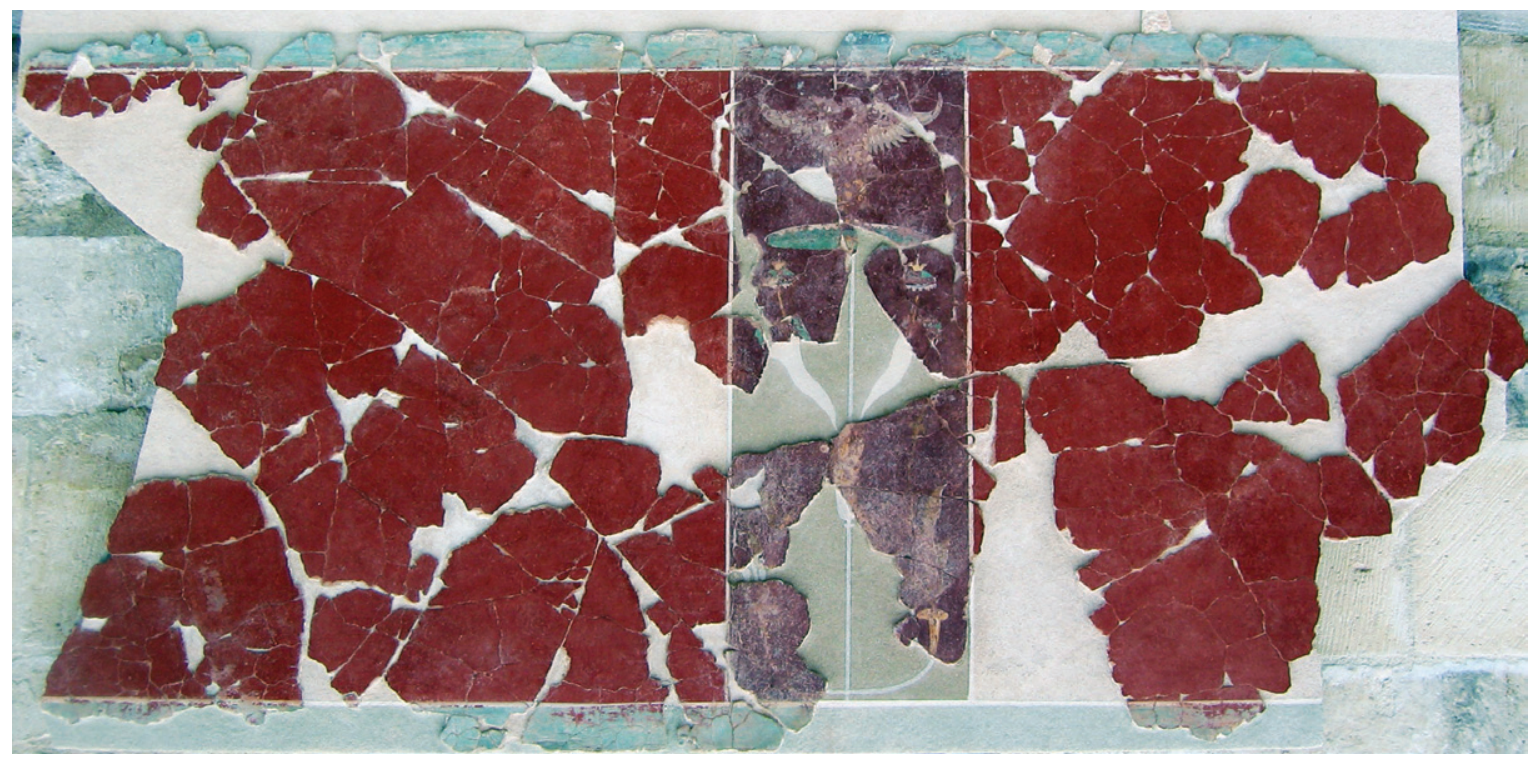

Fig. 10. Aix, 38-42 Boulevard de la République, decoration with candelabra (photo: CEPMR).

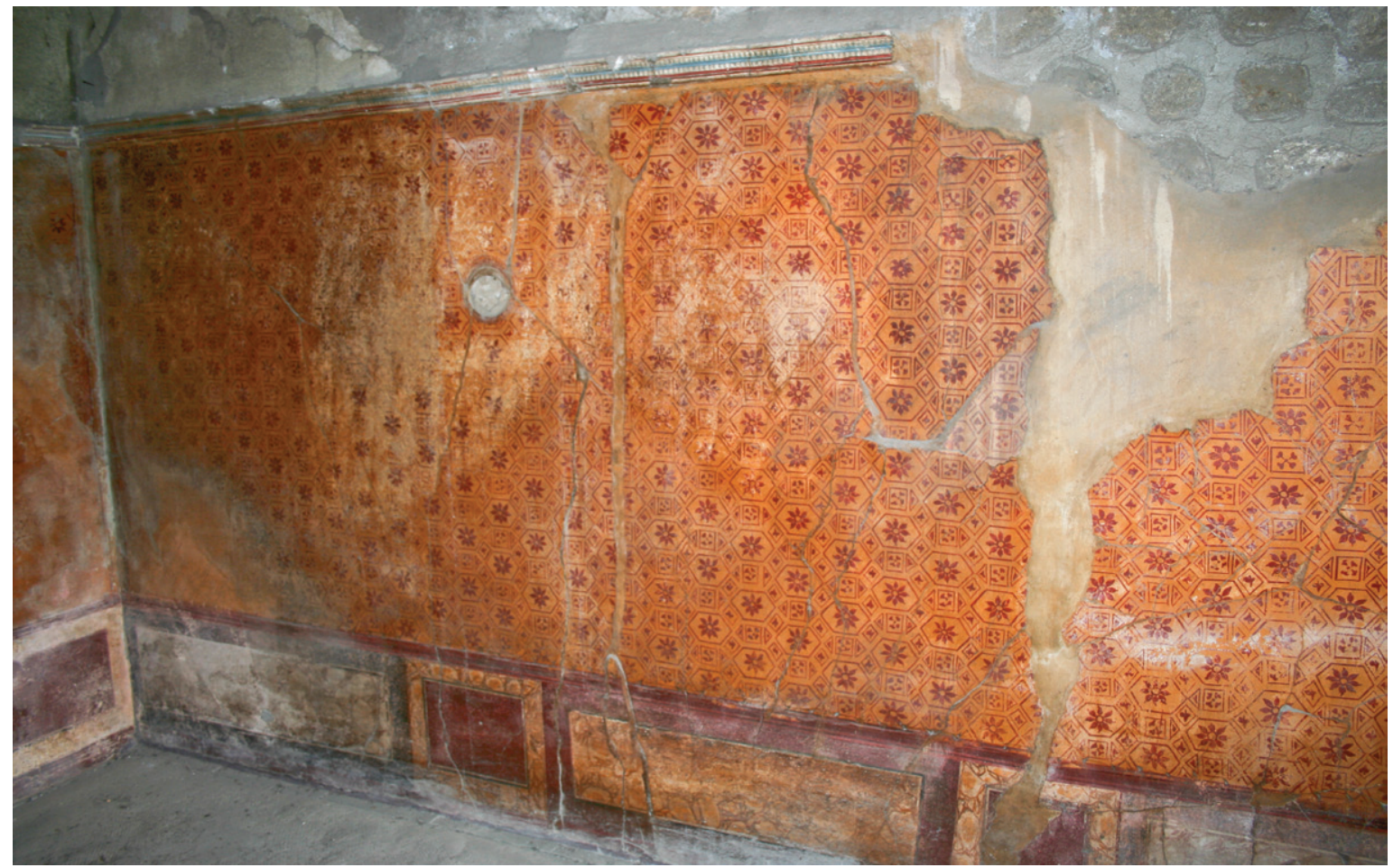

Fig. 11. Narbonne, House with Grand Triclinium, room B, NE wall, wallpaper pattern (DAO: R. Sabrié). 

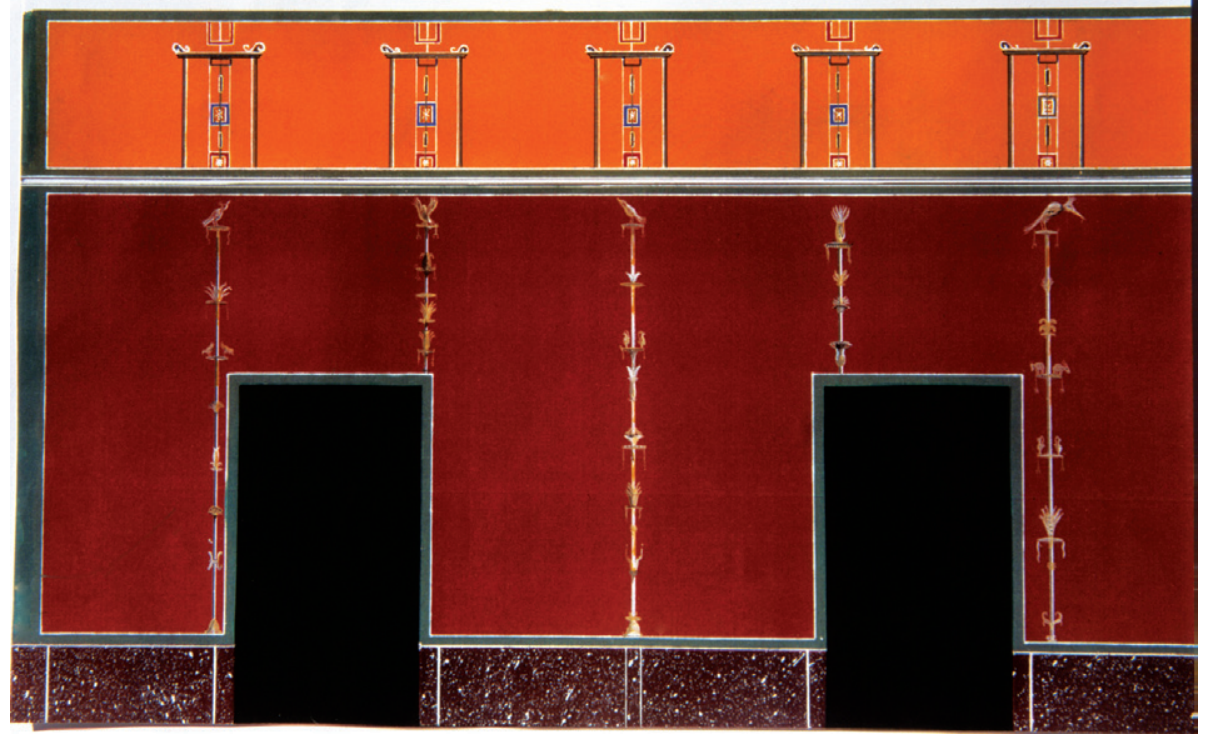

Fig. 12. Fréjus, Place Jules-Formigé, decoration in atrium, S wall (photo: A. Barbet).

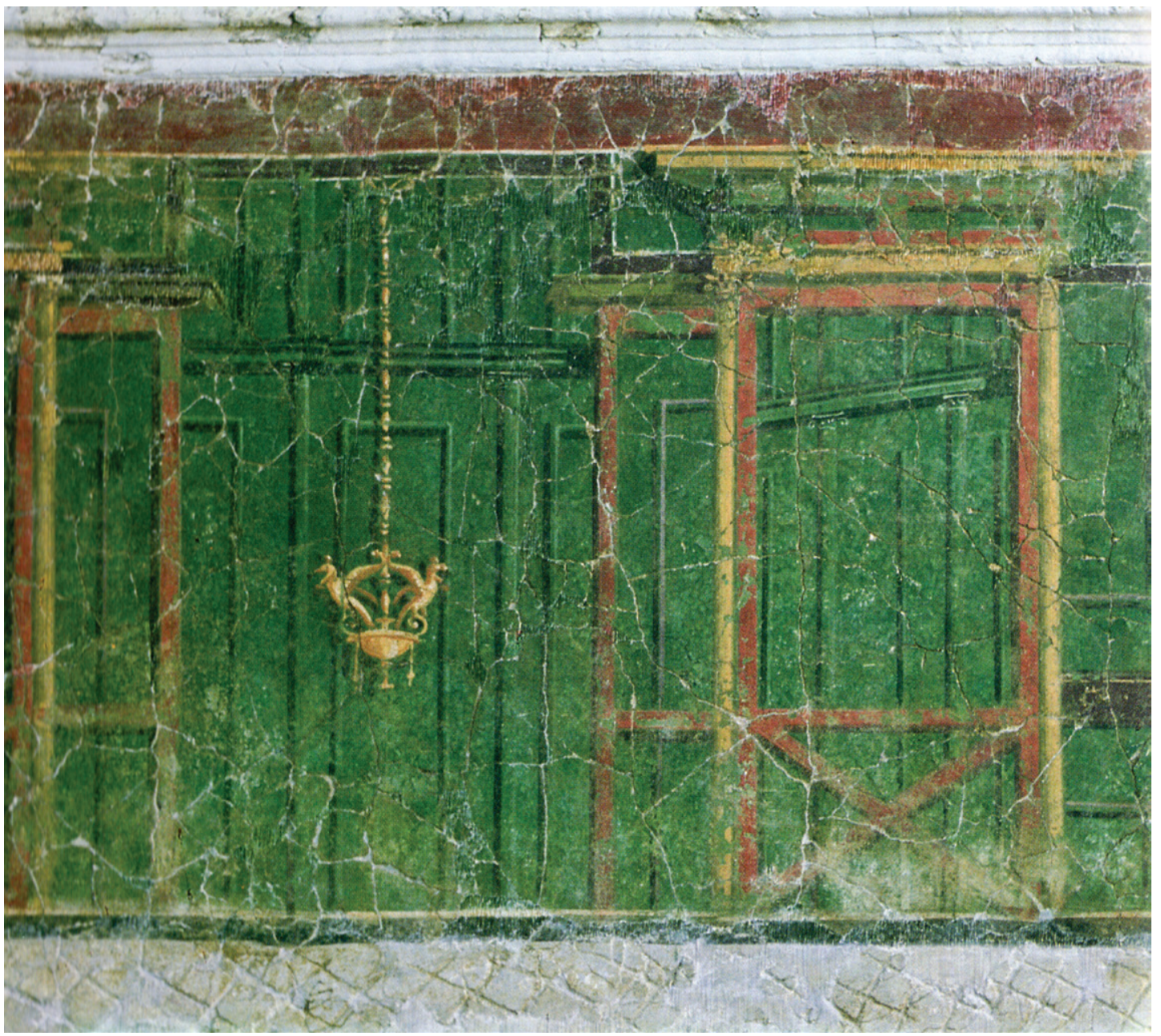

Fig. 13. Narbonne, Maison III, room A, green upper zone (photo: R. Sabrié). 
FIg. 15b. Narbonne, Clos de la Lombarde, Maison IV, detail of decoration with Phaethon (photo: R. Sabrié).

FIg. 16 (below). Schema of divisions of wall-painting (DAO: A. Dardenay and M.-L Maraval).
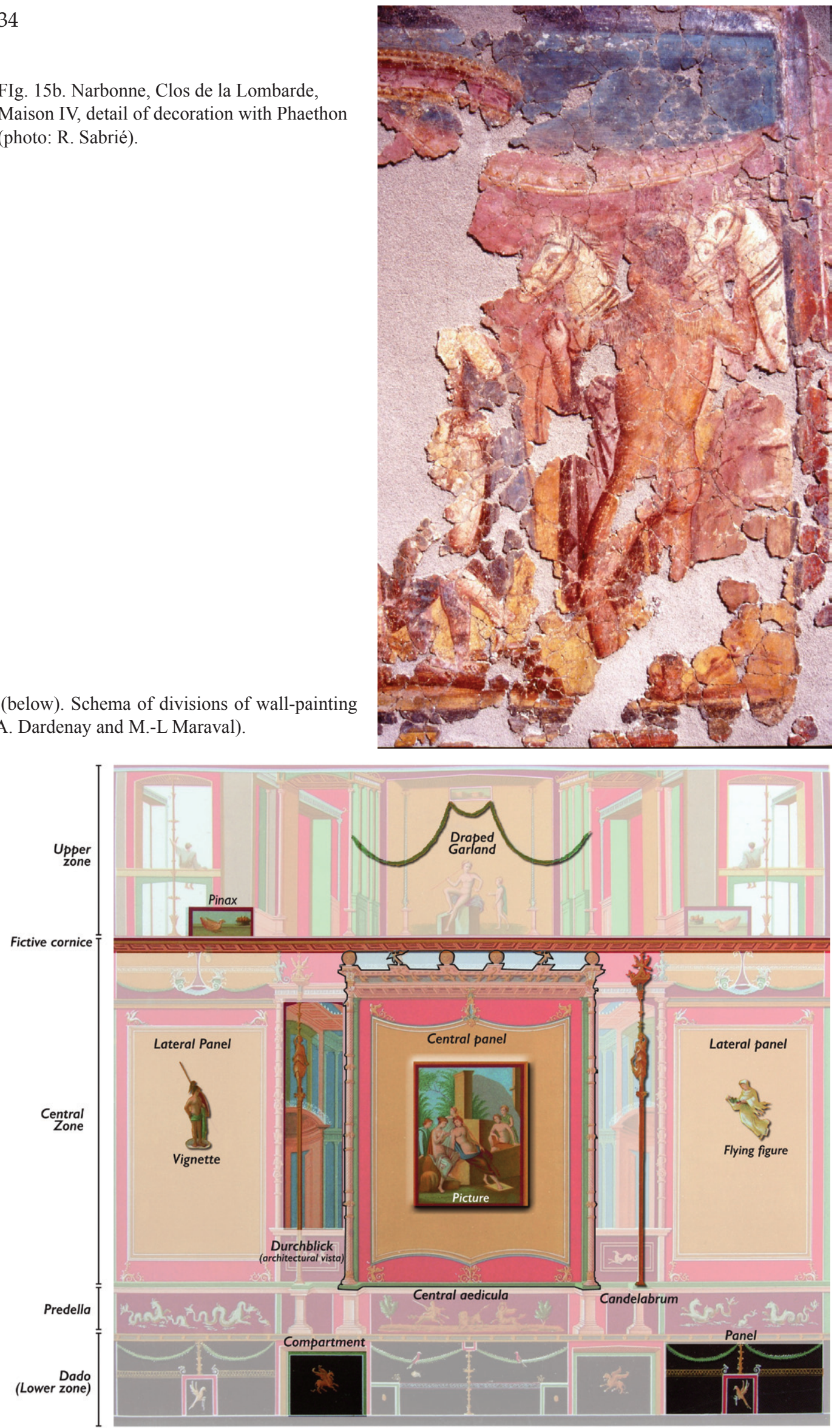


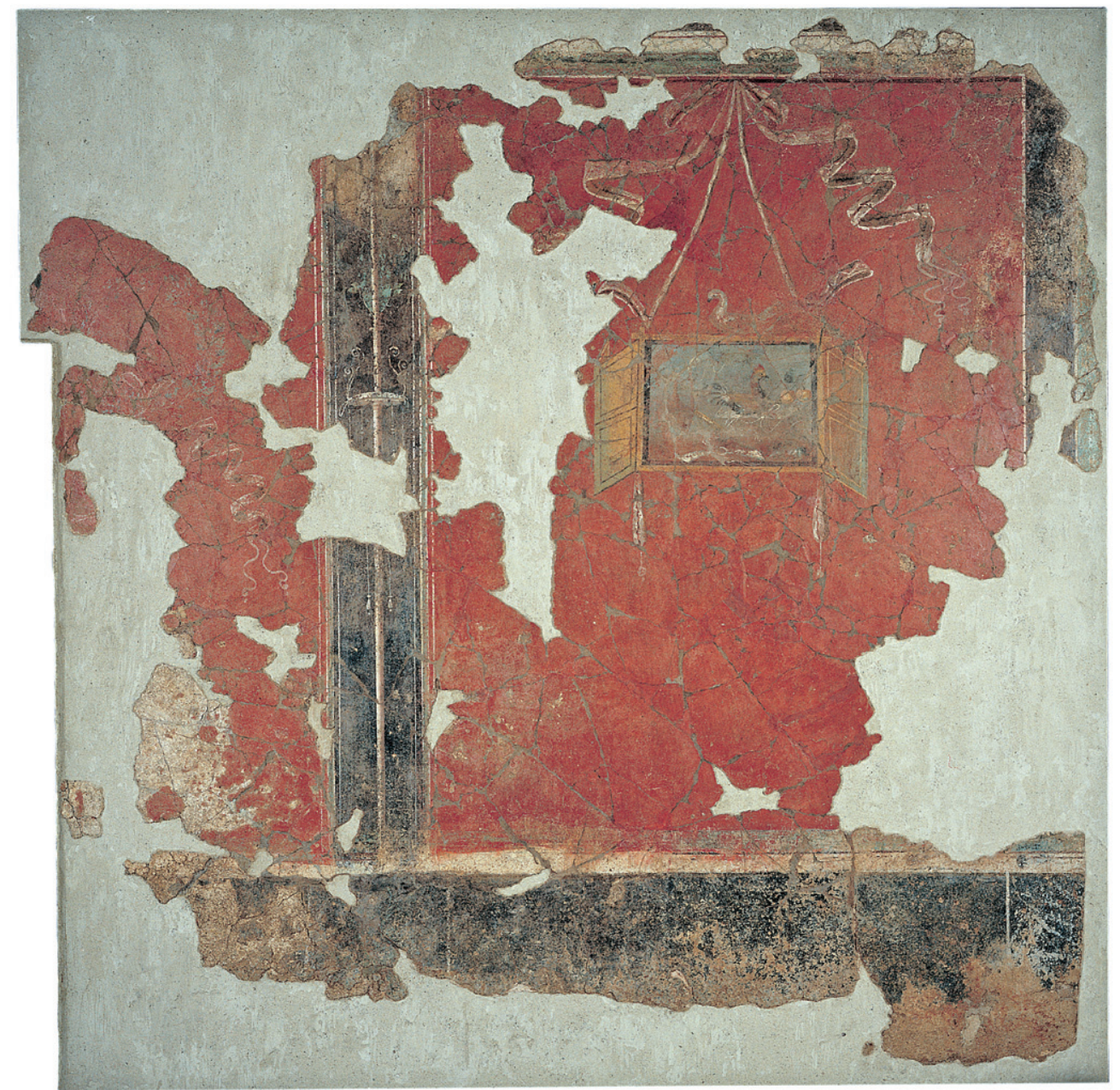

Fig. 17a. (above). Vaise (near Lyon), decoration with candelabra and pinakes (photo: P. Veysseyre).

Fig. 17b. (below). Vaise (near Lyon), detail of pinax with still-life (photo P. Veysseyre).

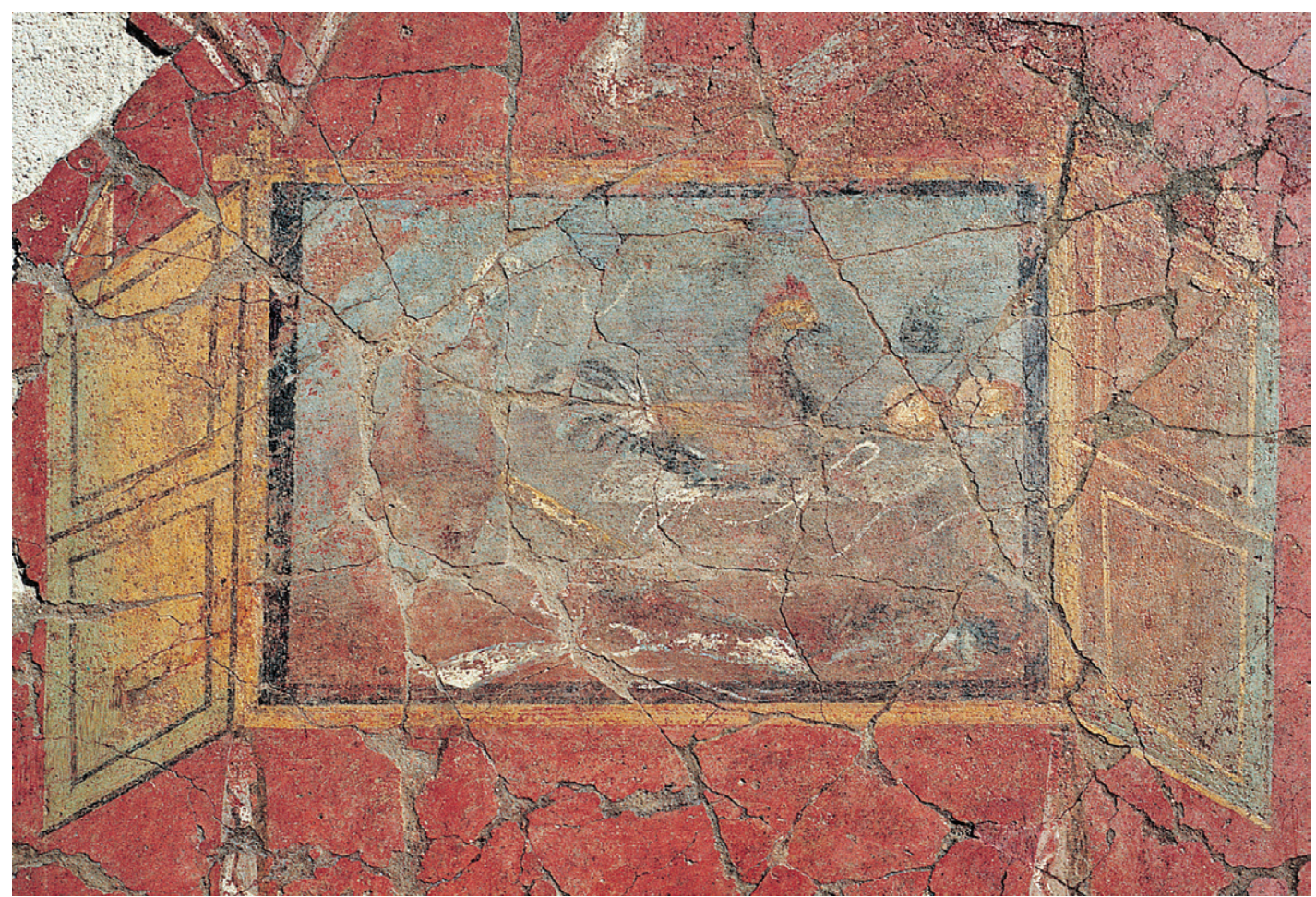




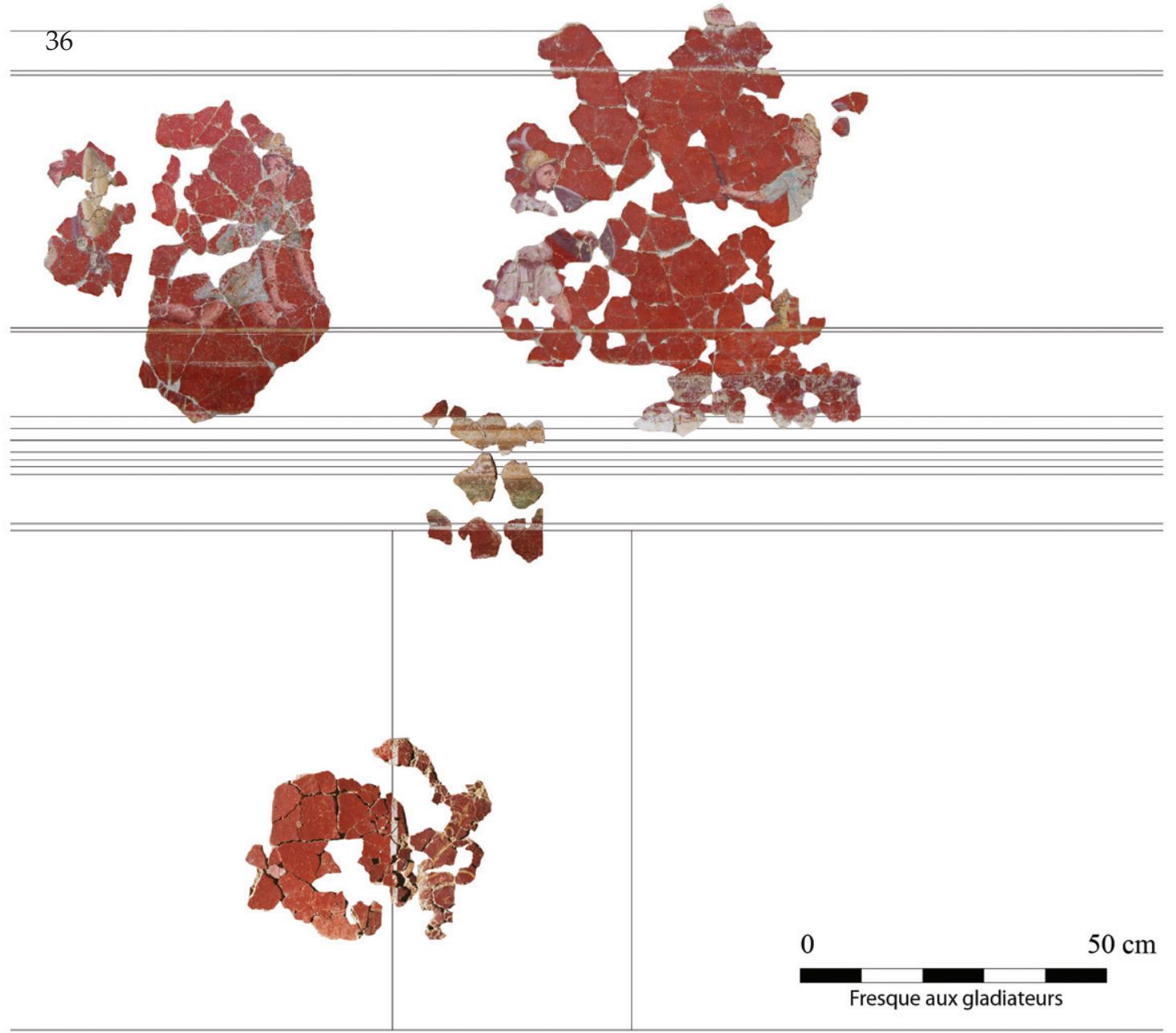

Fig. 18. Aix en Provence, 38-42 Boulevard de la République, frieze with gladiators in upper zone (photo: CEPMR).

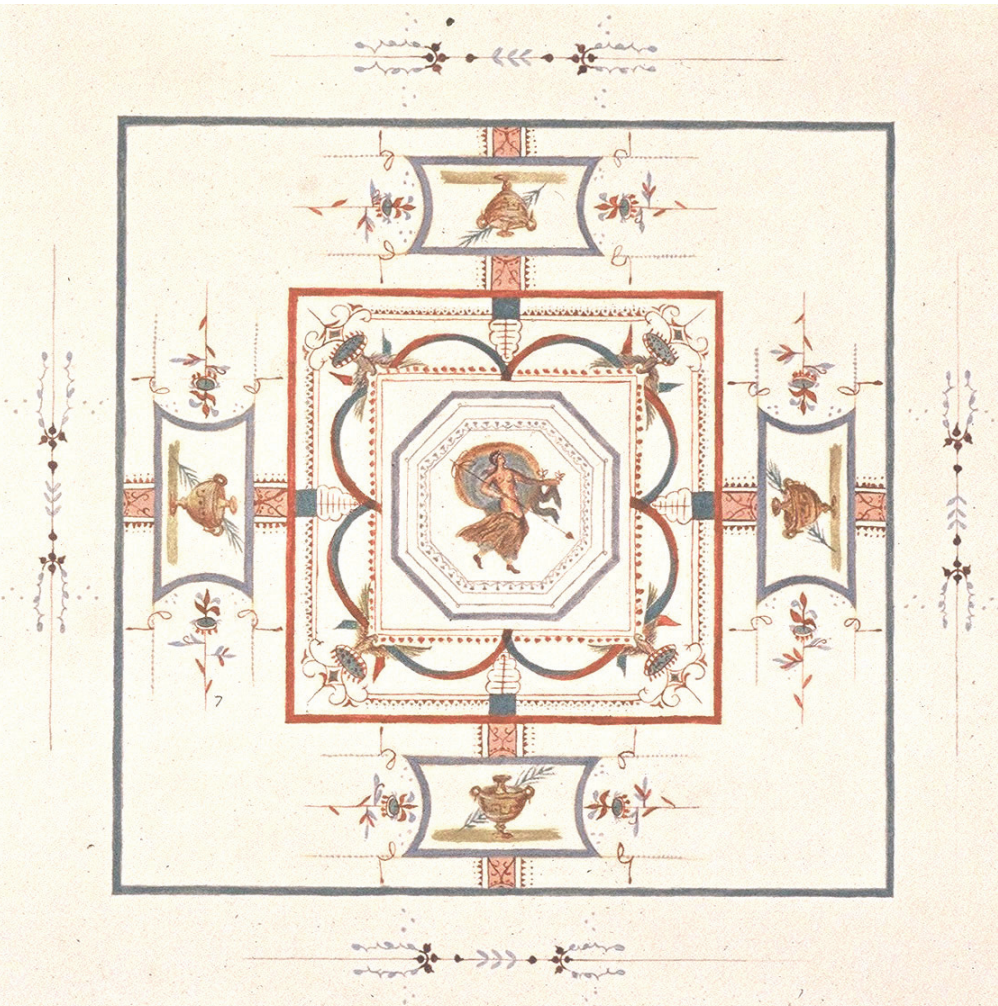

Fig. 19. Narbonne, Clos de la Lombarde, Maison à Portiques, wall $\mathrm{H}$, ceiling (reconstruction: R. Sabrié). 


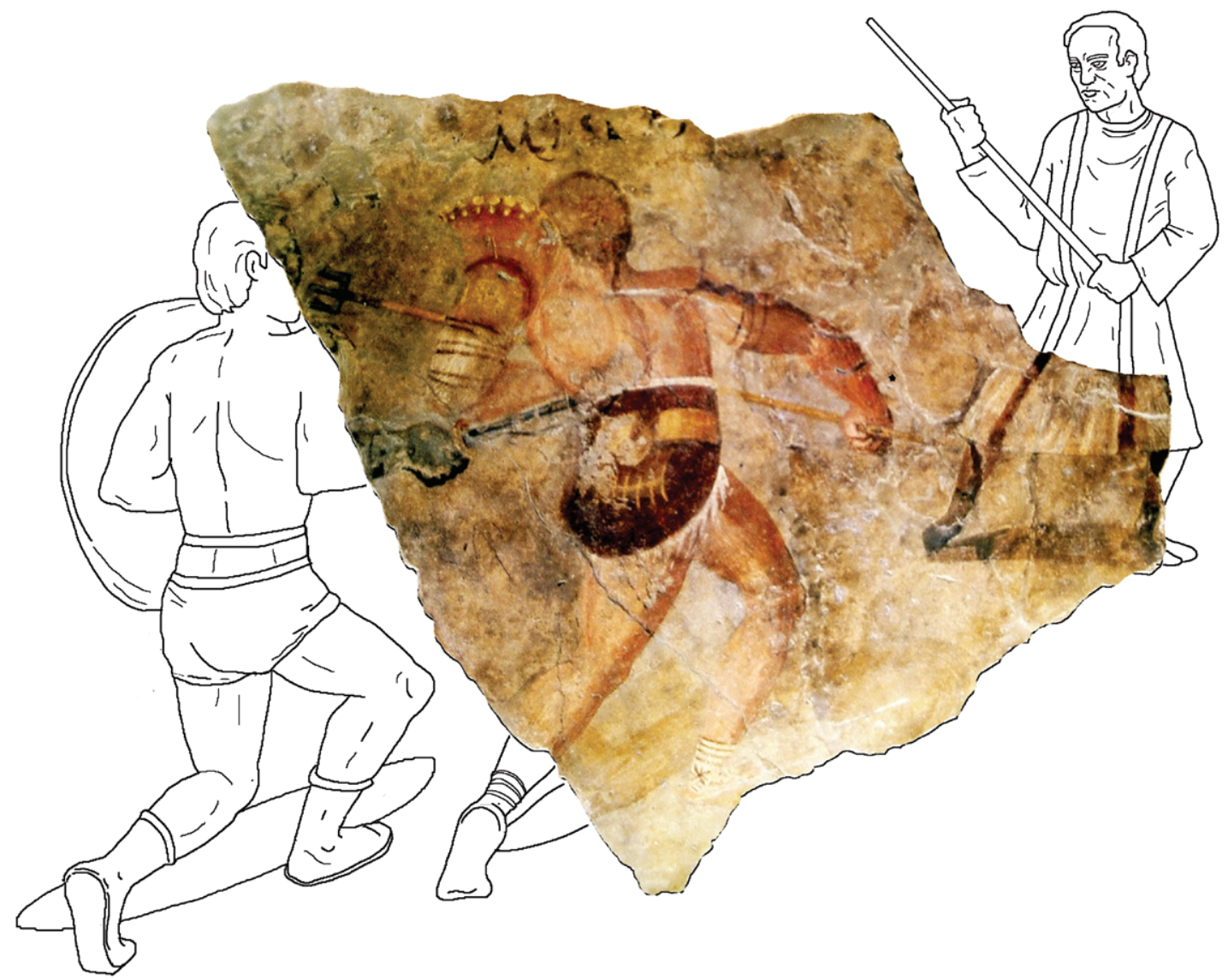

Fig. 20. Périgueux, "Terrain de Lestrade", gladiators (photo A. Barbet).

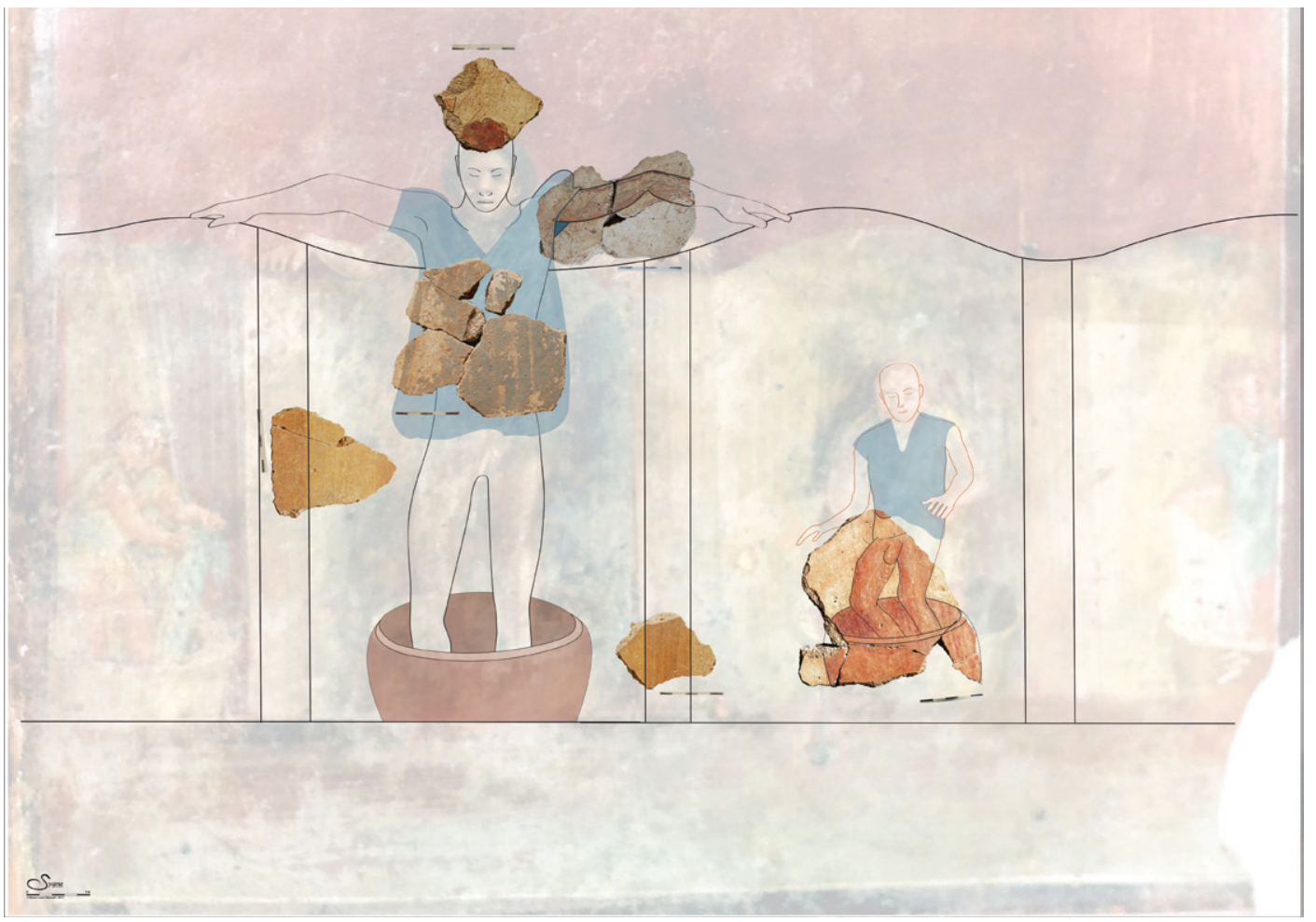

Fig. 21. Castres, la Gourjade, decoration showing fullers at work (reconstruction: A. Dardenay, DAO MLM). 